\title{
Scientific Literature Analysis on Sustainability with the Implication of Open Innovation
}

\author{
Jose Alejandro Cano * $\mathbb{D}$ and Abraham Londoño-Pineda \\ Faculty of Economic and Administrative Sciences, Universidad de Medellin, Medellin 050026, Colombia; \\ alondono@udem.edu.co \\ * Correspondence: jacano@udem.edu.co
}

Received: 13 September 2020; Accepted: 29 October 2020; Published: 22 November 2020

\begin{abstract}
Studies related to sustainability have been performed extensively around the world to evaluate the environmental, economic, and social impact of practices that meet the current and future needs of society. Based on the Scopus database, this study presents a bibliometric analysis for the long, medium, and short term to represent the characteristics of publications related to sustainability, identify research trends and thematic areas with a promising future in research. The analysis covers the following topics: general statistical description, most addressed thematic areas in sustainability, the geographical distribution of sustainability publications, and most influential and cited journals, authors, and articles. The results show sustainability prevails in areas like Engineering, Energy, Environmental Science, and Business, Management, and Accounting, and the publication rate in this field has increased exponentially in the last 10 years. This study also shows that the most productive journals in sustainability research are Sustainability Switzerland and Journal of Cleaner Production, focusing on interdisciplinary and transdisciplinary topics. Likewise, the critical issues of sustainability research are related to sustainable development, humans, environmental sustainability, climate change, decision-making, and environmental impact. As sustainability with open innovation represents a topic with an increasing number of publications, future research can be oriented toward this topic.
\end{abstract}

Keywords: sustainability; sustainable development; bibliometrics; bibliometric analysis; Scopus; citations

\section{Introduction}

At the end of the 1960s, representatives of the Club of Rome argued that infinite economic growth with finite resources was impossible [1]. They informed the world about the risks of following the rising trends in industrial, population, and consumption terms since in the span of 100 years the planet would reach its limits, for which it would be necessary to establish limits to growth, otherwise, an environmental catastrophe of planetary dimensions would occur [2]. In this way, it is comprehended that the relationship between economic growth and the environment represents the origin of the sustainable development debate [3].

Although some conceptualizations about sustainable development emerged 20 years after the 1972 Stockholm Summit, it was only until the Bruntland report that it gained relevance in international politics, emerging the definition of sustainable development as one that guarantees the needs of the present without compromising the possibilities of the future generations to meet their own needs [4]. However, this conceptualization has received various criticisms, because it completely relies on technology as a means to overcome environmental problems, dismissing other aspects such as the power of agreements between the parties involved in the problem [2], and in this sense, the Bruntland Report went from limits to growth toward growth limits [5]. Another criticism of this concept is the 
ambivalence that can generate multiple interpretations since it is not clearly defined what must be sustained and what the present and future needs are [6]. Due to this, new conceptualizations have appeared to delimit the field of study of sustainable development, to the point of exceeding one hundred definitions [7].

In this regard, the concepts of sustainable development and sustainability have given rise to interesting debates [8]. For some authors, sustainable development remains the priority because it represents one of the many development theories [9], while in sustainability the priority is the environment [10]. For other authors, these two concepts may be interchangeable because they pursue the same purposes [11]. However, for authors like Shaker [12], sustainability is the goal and sustainable development is the process to achieve that goal, and in this work, sustainability is understood under the latter concept. Therefore, this study presents a bibliometric review using the term sustainability as a search criterion, being sustainable development one of the multiple components constituting this topic.

Consequently, sustainability can be understood as the result of a minimum performance of the environmental (ecological, natural), economic (business), and social (society) dimensions [13]. Likewise, sustainability is the result of a set of practices that guarantee the use of supplies that does not imply the depletion of resources, does not deteriorate the environment, meets the current and future needs of the society, and maximizes the net benefit of the society when considering all the costs and benefits of these practices $[14,15]$. On the other hand, sustainability depends on a set of rules established by different agents and the government, which must be congruent with the conditions, attributes, local resource systems, and users [16]; and as such, sustainability must be a hallmark of any future infrastructure [17].

In a business context, various tools have been developed aiming to assess corporate sustainability and most of them are linked to international standards like the Global Reporting Initiative (GRI) and the Down Jones Sustainability (DJSI) [18], although some local methodologies can include internal variables of the company, the environment and the relationship with the government [8]. In recent years, some proposals have emerged from addressing sustainability from open innovation, which implies the dynamic interaction of companies with external actors like customers, users, suppliers, universities, research and development centers, competitors, government agencies, neighboring communities, and society [19]. This approach requires a two-way interaction from the company, inside-outside and outside-inside interactions [20], which is more efficient than a one-way interaction to achieve the economic, social, and environmental sustainability goals in companies [21]. Therefore, the subject of sustainability with open innovation requires the articulation of sustainability models [22], external stakeholders [19], two-way interactions [20], the macro and micro dynamics of open innovation [23], among others.

Moreover, the concept of sustainability has transcended the environmental problem, being understood nowadays as a multidimensional phenomenon resulting from development processes involving economic, social, institutional, and environmental problems affecting sectors and citizens of all countries [24]. Currently, concerns about achieving a more sustainable world were embodied in the 17 goals of the 2030 agenda, called Sustainable Development Goals (SDGs), involving both the interests of developed and undeveloped countries. This agenda exceeds the purposes of previous International Summits, where environmental issues represent the prime concern for developed countries, while the least developed countries dealt with development issues since their most pressing problems were related to poverty and hunger [25].

The achievement of the SDGs requires the commitment not only of governments but also of companies, non-governmental organizations, organizations that make up territories and include those researchers who address the scope of sustainability in recent years, since sustainability remains a multidimensional topic involving issues like poverty, hunger, health, education, employment, the reduction of inequalities, climate change, among others. Therefore, these issues require interdisciplinary and transdisciplinary solutions, requiring reviewing the changes presented in the field of sustainability in the last 10 (long term), 5 (medium term), and 2 (short term) years. 
Consequently, the most recent bibliometric analyses of sustainability in the literature have focused on specific themes like the relationship between sustainability and innovation [26], urban sustainability [27], sports tourism and sustainability [28], sustainability and financial performance of small and medium-sized enterprises [29], corporate sustainability [30], strategic management for sustainability [31], healthcare management for sustainability [32], and the issue of sustainability by employing the triple bottom line [33]. However, it is necessary to update the changes in the field of sustainability, including the broad scope of this concept in the long, medium, and short term.

Therefore, this study aims to present a bibliographic analysis on sustainability to determine the most relevant research topics in the short, medium, and long term, and to identify the main research trends in this area that present a vertiginous growth. The remainder of this paper is as follows: Section 2 introduces the methodology employed to perform the bibliometric analysis. In Section 3, the results and findings of the bibliometric analysis are presented considering a short, medium, and long-term horizon. Section 4 details the main conclusions and future research in sustainability.

\section{Materials and Methods}

In the literature, several studies propose techniques to perform comprehensive bibliometric studies. In this regard, Mohadab et al. [34] proposed that the primary sources of information for bibliometric analysis are the Scopus and Web of Science databases, and consequently, a bibliometric work carried out in both databases should include the analysis of authors, institutions, countries, type of document, and domains. Tang et al. [35] suggested that bibliometric studies should perform network analysis, frequency analysis, and keyword centrality analysis to identify the groups of nodes and the size of the nodes that these words represent. Likewise, He et al. [36] proposed a set of bibliometric methods for a comprehensive bibliometric review, which includes the analysis of the number of publications and citations in a period, contributions by country or territory, the distribution of citations in journals, subject categories, general and emerging topics, and the detail of emerging topics. Therefore, our study considers a search for documents published in Scopus between 2011 and 2020 employing several bibliometric techniques that allow classifying information by number of documents, subject area, journals where documents are published, authors' leadership, documents by country, and most cited documents. The main contribution of this study focuses on generating three scenarios for the bibliometric analysis: long, medium, and short term, because sustainability represents a dynamic research topic.

The methodology for the bibliographic analysis on sustainability is based on information obtained from documents published in the Scopus database, related to the area of sustainability for the long term (2011-2020), medium term (2016-2020), and short term (2019-2020). It is clarified that the information included for 2020 corresponds to the first five months of the year since the search process was performed on 31 May 2020. The search equation used was TITLE-ABS-KEY ("Sustainability") to identify the documents including the concept "sustainability" in their title, content, and keywords. With the information obtained with the search equation, we proceeded to analyze for the long, medium, and short term the evolution of scientific production, the number of documents by subject areas, the authors with the highest number of publications, number of documents by country and territory, documents with the highest number of citations and topics of broader relevance. Likewise, the search equation TITLE-ABS-KEY ("Sustainability" AND “Open Innovation") is used to analyze documents related to sustainability and open innovation.

To analyze the thematic areas, the percentage of documents covering the 10 leading thematic areas is presented. The number and percentage of documents published by source related to Sustainability are shown to identify publication sources with the highest scientific production. The detail of the main authors in sustainability includes the Scopus Author ID, number of documents published in Scopus related to sustainability, main subject area, institutional affiliation and territory to which they belong. Moreover, the 20 countries with the highest scientific production related to sustainability are analyzed for each period. The analysis of the most cited documents includes the document title, the topic 
addressed, the authors of the document, and the number of citations in Scopus. On the other hand, the 20 most important research topics in sustainability are analyzed, and a comparative analysis of the evolution over time of the main sustainability topics is equally performed. In this way, the proposed bibliographic analysis on sustainability focuses on determining the most relevant research topics in the short, medium, and long term, and on identifying the main research trends.

\section{Results}

This section presents the main results of the bibliometric analysis on sustainability for the long, medium, and short term, which are equivalent to a periodicity of 10, 5, and 2 years respectively.

\subsection{Research on Sustainability in the Long Term}

Based on the documents available in the literature on sustainability, 218,458 documents were identified in Scopus between 1970 and 2020, as shown in Figure 1. These results show sustainability represents a current area of knowledge in the literature because the number of publications displays exponential growth over time. It is clarified that for 2020 the documents published until May were covered, therefore, the number of publications compared to 2019 is lower. However, when extrapolating the scientific production of sustainability in 2020 based on the production of the first 5 months of the year, an estimate of 27,566 documents is obtained, surpassing the production of 2019, and corroborating the continuous growth of scientific production related to sustainability.

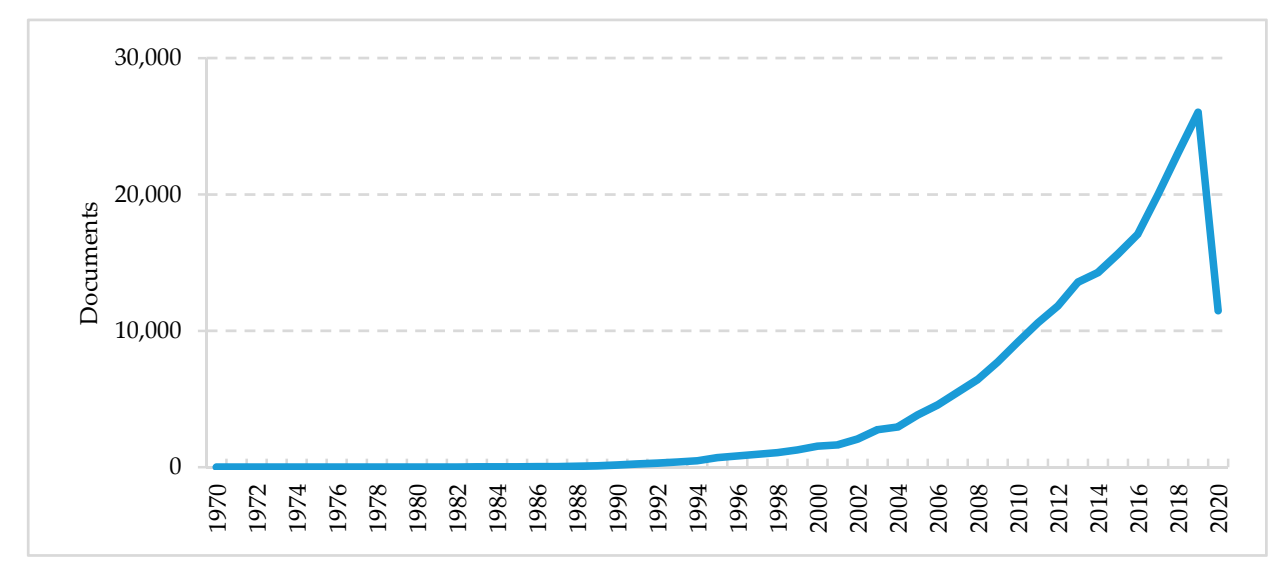

Figure 1. Documents published on sustainability between 1970 and 2020.

Analyzing the last 10 years of research on sustainability, 163,581 documents are identified, which is equivalent to $74.9 \%$ of the total publications on sustainability, therefore, this area of knowledge has experienced its boom in the course of the past decade, to the point of generating 26,026 documents in 2019 and 11,486 in the first 5 months of 2020. Regarding the leading thematic areas on sustainability in the last 10 years, Table 1 shows that these correspond to Environmental Sciences, Social Sciences, Engineering, Energy, Business Management and Accounting, Biological Sciences, covering $67.8 \%$ of the total publications.

Table 1. Documents by subject areas.

\begin{tabular}{cc}
\hline Subject Area & \% Documents \\
\hline Environmental Science & $17.5 \%$ \\
Social Sciences & $14.9 \%$ \\
Engineering & $11.9 \%$ \\
Energy & $8.2 \%$ \\
Business, Management and Accounting & $8.1 \%$ \\
Agricultural and Biological Sciences & $7.3 \%$ \\
\hline
\end{tabular}


Table 1. Cont.

\begin{tabular}{cc}
\hline Subject Area & \% Documents \\
\hline Computer Science & $4.5 \%$ \\
Economics, Econometrics and Finance & $4.3 \%$ \\
Medicine & $3.7 \%$ \\
Earth and Planetary Sciences & $3.0 \%$ \\
Others & $16.7 \%$ \\
\hline
\end{tabular}

Table 2 shows the journals publishing the largest number of documents on sustainability, detailing the first 15 publications that together published approximately $11.9 \%$ of the sustainability documents in Scopus in the last 10 years. It is highlighted that Sustainability Switzerland and Journal of Cleaner Production are leaders in the area of sustainability, representing $6.8 \%$ of the total publications in the last 10 years. It is noted that Sustainability Switzerland focuses on interdisciplinary issues of environmental, cultural, economic, and social sustainability, while Journal of Cleaner Production focuses on transdisciplinary issues of cleaner production, environment, and sustainability.

Table 2. Journals on sustainability between 2011 and 2020.

\begin{tabular}{ccc}
\hline Journal & Documents & \% Documents \\
\hline Sustainability Switzerland & 7178 & $4.4 \%$ \\
\hline Journal Of Cleaner Production & 4008 & $2.5 \%$ \\
\hline Iop Conference Series Earth And Environmental Science & 1029 & $0.6 \%$ \\
\hline Science Of The Total Environment & 997 & $0.6 \%$ \\
\hline Renewable And Sustainable Energy Reviews & 757 & $0.5 \%$ \\
\hline Ecological Indicators & 625 & $0.4 \%$ \\
\hline Journal Of Environmental Management & 624 & $0.4 \%$ \\
\hline Iop Conference Series Materials Science And Engineering & 575 & $0.4 \%$ \\
\hline PLoS ONE & 559 & $0.3 \%$ \\
\hline Wit Transactions On Ecology And The Environment & 554 & $0.3 \%$ \\
\hline Resources Conservation And Recycling & 549 & $0.3 \%$ \\
\hline Notes In Artificial Intelligence And Lecture Notes In Bioinformatics & 506 & $0.3 \%$ \\
\hline Applied Energy & 502 & $0.3 \%$ \\
\hline Energy Policy & 500 & $0.3 \%$ \\
\hline Ecological Economics & 484 & $0.3 \%$ \\
\hline
\end{tabular}

On the other hand, Table 3 indicates the authors generating the largest number of sustainability documents in the last 10 years, therefore indicating those authors with more than 60 publications, that is, with an average production rate of more than six documents per year. From Table 3, it is observed that the main authors in the last 10 years are working in thematic areas related to Engineering, Environmental Science, Energy, and Business, Management and Accounting. In addition, these authors belong to diverse universities and territories including North America, Europe, Asia, and Africa. 
Table 3. Leading authors on sustainability in the last 10 years.

\begin{tabular}{|c|c|c|c|c|c|c|}
\hline Author & Scopus Author ID & Docs. ${ }^{*}$ & $\begin{array}{l}h \text {-Index and } \\
\text { Citations }\end{array}$ & Main Subject Area & Affiliation & Country/Territory \\
\hline Dincer, I. & 56278550500 & 101 & $\begin{array}{c}\text { h-index: } 91 \\
\text { 36,621 citations by } \\
\text { 19,711 documents }\end{array}$ & $\begin{array}{c}\text { Energy } \\
\text { Engineering } \\
\text { Physics and Astronomy } \\
\text { Environmental Science } \\
\text { Chemical Engineering }\end{array}$ & $\begin{array}{c}\text { 2003-2020 Ontario Tech University. } \\
\text { 2016-2020 Yildiz } \\
\text { Technical University. }\end{array}$ & $\begin{array}{l}\text { Oshawa, Canada. } \\
\text { Istanbul, Turkey. }\end{array}$ \\
\hline Sarkis, J. & 57194726123 & 98 & $\begin{array}{c}\text { h-index: } 81 \\
27,237 \text { citations by } \\
14,593 \text { documents }\end{array}$ & $\begin{array}{l}\text { Business, Management } \\
\text { and Accounting } \\
\text { Engineering } \\
\text { Decision Sciences } \\
\text { Environmental Science } \\
\text { Economics, Econometrics } \\
\text { and Finance }\end{array}$ & $\begin{array}{c}\text { 2013-2020 Worcester } \\
\text { Polytechnic Institute. } \\
\text { 2015-2020 Foisie Business School. } \\
\text { 2019-2020 Hanken School of } \\
\text { Economics. }\end{array}$ & $\begin{array}{c}\text { Worcester, United States. } \\
\text { Worcester, United States. } \\
\text { Helsinki, Finland. }\end{array}$ \\
\hline Azapagic, A. & 54967174100 & 88 & $\begin{array}{c}\text { h-index: } 47 \\
7650 \text { citations by } 6103 \\
\text { documents }\end{array}$ & $\begin{array}{l}\text { Environmental Science } \\
\text { Engineering } \\
\text { Energy } \\
\text { Chemical Engineering } \\
\text { Business, Management } \\
\text { and Accounting }\end{array}$ & $\begin{array}{l}\text { 2007-2020 Department of Chemical } \\
\text { Engineering and Analytical Science. } \\
\text { 2007-2020 University of Manchester. } \\
\text { 2014-2015 Brunel University London. }\end{array}$ & $\begin{array}{l}\text { Manchester, } \\
\text { United Kingdom. } \\
\text { Manchester, } \\
\text { United Kingdom. } \\
\text { Uxbridge, } \\
\text { United Kingdom. }\end{array}$ \\
\hline Lal, R. & 55444564800 & 67 & $\begin{array}{c}\text { h-index: } 103 \\
\text { 50,538 citations by } \\
\text { 30,465 documents }\end{array}$ & $\begin{array}{c}\text { Agricultural and } \\
\text { Biological Sciences } \\
\text { Environmental Science } \\
\text { Earth and Planetary Sciences } \\
\text { Engineering } \\
\text { Social Sciences } \\
\end{array}$ & $\begin{array}{l}\text { 1988-2020 The Ohio State University. } \\
\text { 2013-2019 Indian Institute of } \\
\text { Technology Delhi. } \\
\text { 2015-2018 Banaras Hindu University. }\end{array}$ & $\begin{array}{l}\text { Columbus, United States. } \\
\text { New Delhi, India. } \\
\text { Varanasi, India. }\end{array}$ \\
\hline Penzenstadler, B. & 24765180000 & 67 & $\begin{array}{c}\text { h-index: } 20 \\
1108 \text { citations by } 585 \\
\text { documents }\end{array}$ & $\begin{array}{l}\text { Computer Science } \\
\text { Engineering Social } \\
\text { Sciences } \\
\text { Mathematics } \\
\text { Business, Management } \\
\text { and Accounting }\end{array}$ & $\begin{array}{l}\text { 2019-2020 Chalmers University } \\
\text { of Technology. } \\
\text { 2015-2019 California State } \\
\text { University Long Beach. } \\
\text { 2019 Lappeenrannan Teknillinen } \\
\text { Yliopisto. }\end{array}$ & $\begin{array}{l}\text { Göteborg, Sweden. } \\
\text { Long Beach, } \\
\text { United States. } \\
\text { Lappeenranta, Finland. }\end{array}$ \\
\hline Schaltegger, S. & 6602922601 & 67 & $\begin{array}{c}\text { h-index: } 38 \\
5955 \text { citations by } 4108 \\
\text { documents }\end{array}$ & $\begin{array}{l}\text { Business, Management } \\
\text { and Accounting } \\
\text { Environmental Science } \\
\text { Social Sciences } \\
\text { Economics, Econometrics } \\
\text { and Finance } \\
\text { Energy }\end{array}$ & $\begin{array}{l}\text { 2001-2020 Leuphana Universität } \\
\text { Lüneburg. } \\
\text { 1996-2017 Universitat Basel. } \\
\text { 2014-2015 Centre for Sustainability } \\
\text { Management CSM. }\end{array}$ & $\begin{array}{l}\text { Luneburg, Germany. } \\
\text { Basel, Switzerland. } \\
\text { Luneburg, Germany. }\end{array}$ \\
\hline
\end{tabular}


Table 3. Cont.

\begin{tabular}{|c|c|c|c|c|c|c|}
\hline Author & Scopus Author ID & Docs. ${ }^{*}$ & $\begin{array}{l}h \text {-Index and } \\
\text { Citations }\end{array}$ & Main Subject Area & Affiliation & Country/Territory \\
\hline Germani, M. & 7003708542 & 66 & $\begin{array}{c}\text { h-index: } 18 \\
1792 \text { citations by } 1343 \\
\text { documents }\end{array}$ & $\begin{array}{c}\text { Engineering } \\
\text { Computer Science } \\
\text { Mathematics } \\
\text { Business, Management and } \\
\text { Accounting } \\
\text { Energy }\end{array}$ & $\begin{array}{c}\text { 2003-2020 Università Politecnica } \\
\text { delle Marche. } \\
2008 \text { University of Ferrara. }\end{array}$ & $\begin{array}{l}\text { Ancona, Italy. } \\
\text { Ferrara, Italy. }\end{array}$ \\
\hline Mbohwa, C. & 6603262827 & 66 & $\begin{array}{l}\text { h-index: } 17 \\
1116 \text { citations by } 988 \\
\text { documents }\end{array}$ & $\begin{array}{c}\text { Engineering } \\
\text { Business, Management and } \\
\text { Accounting } \\
\text { Decision Sciences } \\
\text { Computer Science } \\
\text { Energy } \\
\end{array}$ & $\begin{array}{l}\text { 2009-2020 University of } \\
\text { Johannesburg, Johannesburg. } \\
2019 \text { University of Science } \\
\text { and Technology. } \\
2019 \text { University of Johannesburg. }\end{array}$ & $\begin{array}{l}\text { South Africa. } \\
\text { Botswana. } \\
\text { Johannesburg, } \\
\text { South Africa. }\end{array}$ \\
\hline Ren, J. & 35220394000 & 65 & $\begin{array}{c}\text { h-index: } 31 \\
2924 \text { citations by } 2085 \\
\text { documents }\end{array}$ & $\begin{array}{c}\text { Energy } \\
\text { Environmental Science } \\
\text { Engineering } \\
\text { Business, Management and } \\
\text { Accounting } \\
\text { Chemical Engineering }\end{array}$ & $\begin{array}{l}\text { 2017-2020 Hong Kong } \\
\text { Polytechnic University. } \\
\text { 2015-2018 Syddansk Universitet. } \\
\text { 2012-2017 Università degli Studi } \\
\text { di Padova. }\end{array}$ & $\begin{array}{l}\text { Kowloon, Hong Kong. } \\
\text { Odense, Denmark. } \\
\text { Padua, Italy. }\end{array}$ \\
\hline Klemeš, J.J. & 56903012000 & 64 & $\begin{array}{c}\text { h-index: } 54 \\
\text { 10,746 citations by } \\
6098 \text { documents }\end{array}$ & $\begin{array}{c}\text { Engineering } \\
\text { Environmental Science } \\
\text { Chemical } \\
\text { Engineering } \\
\text { Energy }\end{array}$ & $\begin{array}{l}\text { 2017-2020 Brno University } \\
\text { of Technology. } \\
2019 \text { Islamic Azad University. }\end{array}$ & $\begin{array}{l}\text { Brno, Czech Republic. } \\
\text { Tehran, Iran. }\end{array}$ \\
\hline
\end{tabular}

* Documents published in Scopus in 2011-2020 related to sustainability. 
Figure 2 shows the 20 countries with the most significant scientific production related to sustainability ( $71.1 \%$ of scientific production on sustainability in the last 10 years), indicating that the United States represents the leading country in publications, and sustainability is widely addressed globally with the highest publication rates in countries in North America, Europe, Asia, Oceania, and South America.

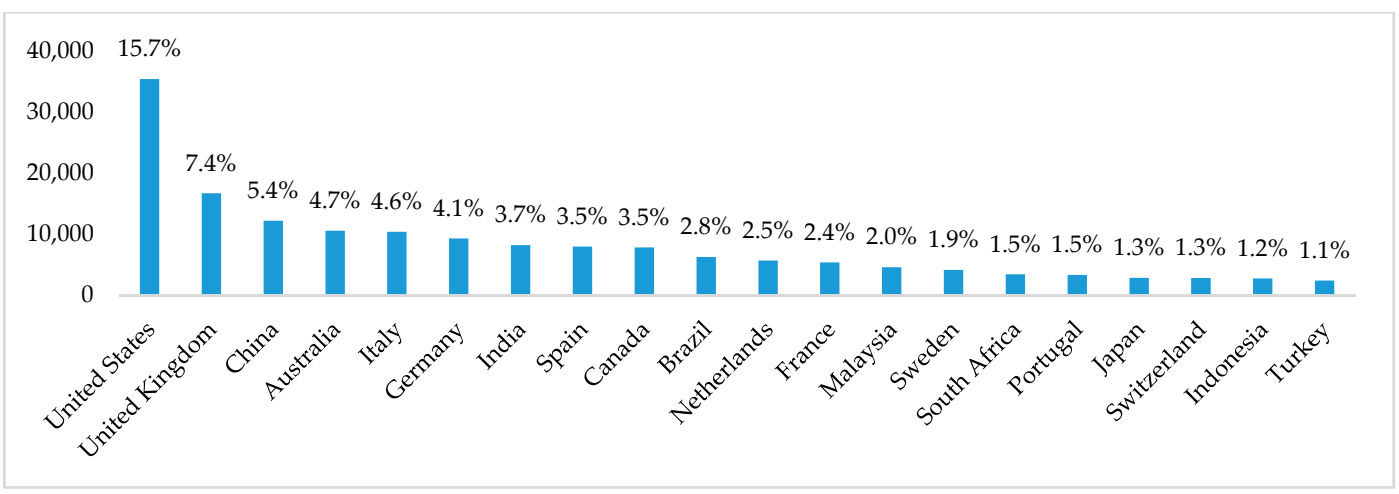

Figure 2. Documents by country published on sustainability between 2011 and 2020.

On the other hand, Table 4 lists the 10 most cited articles addressing the issue of sustainability, which receive an average annual citation between 119 and 293 citations. The topics covered by these documents are diverse, including environment, agricultural science, energy, engineering, chemistry, materials science, food, and corporate social responsibility.

Table 4. Most cited documents between 2011 and 2020.

\begin{tabular}{|c|c|c|c|}
\hline Document Title & Topics & Authors & Cites \\
\hline Solutions for a cultivated planet & $\begin{array}{l}\text { Solutions to double food production while greatly reducing } \\
\text { the environmental impacts of agriculture. }\end{array}$ & [37] & 2937 \\
\hline $\begin{array}{l}\text { The future of seawater } \\
\text { desalination: Energy, technology, } \\
\text { and the environment }\end{array}$ & $\begin{array}{l}\text { Possible reductions in energy demand by seawater } \\
\text { desalination technologies. The sustainability of desalination } \\
\text { as a technological solution to global water shortages. }\end{array}$ & [38] & 2534 \\
\hline $\begin{array}{l}\text { Biodiversity loss and its impact } \\
\text { on humanity }\end{array}$ & $\begin{array}{l}\text { How loss of biological diversity will alter the functioning of } \\
\text { ecosystems and their ability to provide society with the } \\
\text { goods and services needed to prosper. }\end{array}$ & [39] & 2505 \\
\hline $\begin{array}{l}\text { Towards greener and more } \\
\text { sustainable batteries for } \\
\text { electrical energy storage }\end{array}$ & $\begin{array}{l}\text { An overview of the current state of energy storage (batteries) } \\
\text { from a sustainability perspective considering elemental } \\
\text { abundance, toxicity, synthetic methods, and scalability. } \\
\text { The complexity and importance of recycling battery } \\
\text { materials are also discussed. }\end{array}$ & [40] & 2421 \\
\hline $\begin{array}{l}\text { Advanced Engineering } \\
\text { Thermodynamics }\end{array}$ & $\begin{array}{l}\text { A book that bridges the gap between engineering } \\
\text { applications and the first and second laws of } \\
\text { thermodynamics, describing real-world applications of } \\
\text { thermodynamics concepts, including solar energy, } \\
\text { refrigeration, air conditioning, thermofluid design, chemical } \\
\text { design, constructal design, and more, linking new } \\
\text { technologies in sustainability to fundamental } \\
\text { thermodynamics concepts. }\end{array}$ & [41] & 2290 \\
\hline $\begin{array}{l}\text { Graphitic Carbon Nitride } \\
\text { (g-C3 N4)-Based Photocatalysts } \\
\text { for Artificial Photosynthesis and } \\
\text { Environmental Remediation: } \\
\text { Are We a Step Closer to } \\
\text { Achieving Sustainability? }\end{array}$ & $\begin{array}{l}\text { A review summarizing a panorama of the latest progress } \\
\text { related to the design and construction of pristine g-C3N4 } \\
\text { (graphitic carbon nitride) and g-C3N4-based } \\
\text { nanocomposites. This review can stimulate new research for } \\
\text { the development of a sustainable future without } \\
\text { environmental detriment. }\end{array}$ & [42] & 2194 \\
\hline
\end{tabular}


Table 4. Cont.

\begin{tabular}{|c|c|c|c|}
\hline Document Title & Topics & Authors & Cites \\
\hline $\begin{array}{l}\text { Biocomposites reinforced with } \\
\text { natural fibers: } 2000-2010\end{array}$ & $\begin{array}{l}\text { A comprehensive literature review (from } 2000 \text { to 2010) on } \\
\text { the most readily utilized natural fibers and biopolymers. } \\
\text { The wide variety of biocomposite processing techniques as } \\
\text { well as the factors affecting these processes are discussed. } \\
\text { This study presents recent developments and future trends } \\
\text { of biocomposites as well as key issues that need to be } \\
\text { addressed and resolved. }\end{array}$ & [43] & 1814 \\
\hline $\begin{array}{c}\text { Global forecasts of urban } \\
\text { expansion to } 2030 \text { and direct } \\
\text { impacts on biodiversity and } \\
\text { carbon pools }\end{array}$ & $\begin{array}{l}\text { This study develops spatially explicit probabilistic forecasts } \\
\text { of global urban land-cover change and explores the direct } \\
\text { impacts on biodiversity hotspots and tropical carbon } \\
\text { biomass. The aggregate global impacts of projected urban } \\
\text { expansion will require significant policy changes to affect } \\
\text { future growth trajectories to minimize global biodiversity } \\
\text { and vegetation carbon losses. }\end{array}$ & [44] & 1272 \\
\hline $\begin{array}{l}\text { Global land use change, } \\
\text { economic globalization, and the } \\
\text { looming land scarcity }\end{array}$ & $\begin{array}{l}\text { This study analyzes policies and innovations that can } \\
\text { reconcile forest preservation with food production, } \\
\text { especially for developing countries. A central challenge for } \\
\text { sustainability is how to preserve forest ecosystems and the } \\
\text { services that they provide while enhancing food production. }\end{array}$ & [45] & 1243 \\
\hline $\begin{array}{c}\text { What We Know and Don't } \\
\text { Know About Corporate Social } \\
\text { Responsibility: A Review and } \\
\text { Research Agenda }\end{array}$ & $\begin{array}{c}\text { A review of corporate social responsibility (CSR) literature, } \\
\text { offering a multilevel and multidisciplinary theoretical } \\
\text { framework that synthesizes and integrates the literature at } \\
\text { the institutional, organizational, and individual } \\
\text { levels of analysis. }\end{array}$ & [46] & 1192 \\
\hline
\end{tabular}

Regarding the research topics, Figure 3 shows the 20 most relevant topics between 2011 and 2020 in the 163,581 documents found in the literature, highlighting the topics of sustainable development, humans, environmental sustainability, climate change, environmental impact, decision-making, and economics, therefore reflecting the three triple bottom line (social, economic, and environmental dimensions).

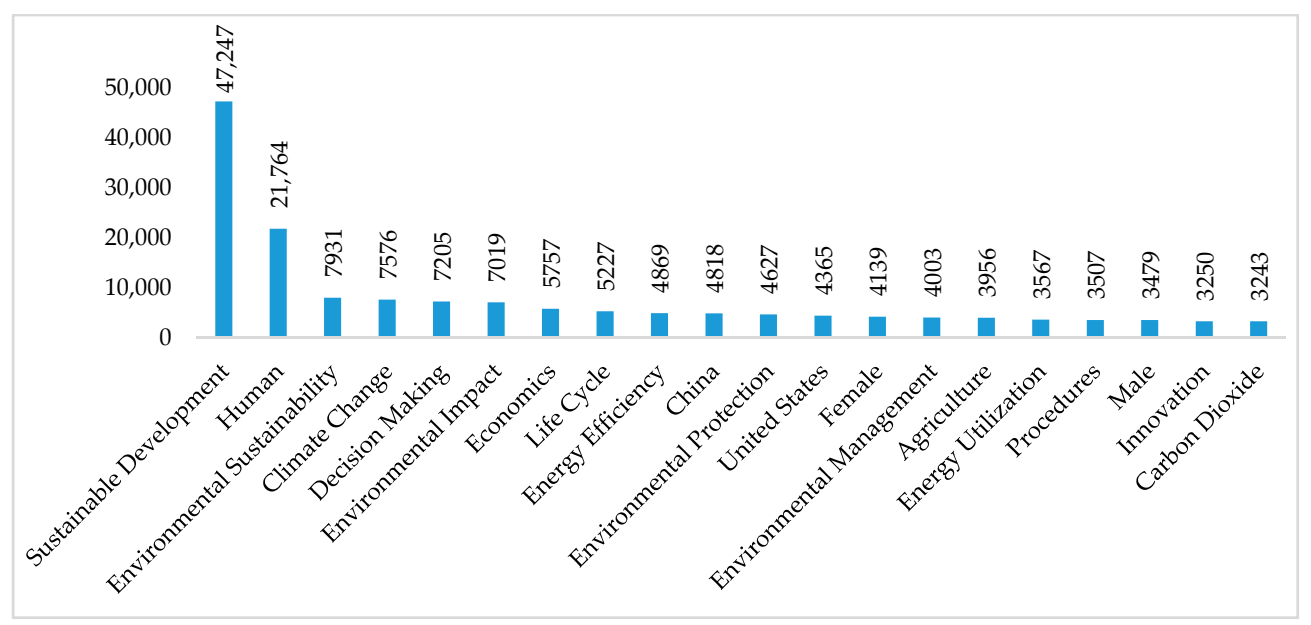

Figure 3. Sustainability research topics between 2011 and 2020.

\subsection{Research on Sustainability in the Medium Term (5 Years)}

From the publications on sustainability found in the literature, 97,689 documents (44.7\%) were published between 2016 and 2020, showing approximately half of the existing literature on sustainability has emerged in the last five years, confirming the current relevance of this knowledge area which is transversal to thematic areas like environmental sciences, social sciences, engineering, energy, business, management and accounting, biological and agricultural sciences, computer science, economics and 
finance, medicine, earth sciences, among others, because these subject areas had the same relevance between 2016 and 2020 as between 2011 and 2020, as evidenced in Table 1 .

Based on Table 5, Sustainability Switzerland, Journal Of Cleaner Production, Iop Conference Series Earth And Environmental Science, and Science Of The Total Environment continue to be the journals and publications with the largest number of articles on sustainability, providing the $11.9 \%$ of all publications on sustainability in the last 5 years. In contrast to the main publications between 2011 and 2020 shown in Table 2, Table 5 highlights that Iop Conference Series Materials Science And Engineering goes from being the eighth publication to being the fifth publication with the largest number of documents in the last five years, Resources Conservation And Recycling moves up from eleven to eight, Renewable And Sustainable Energy Reviews goes from five to six, and Ecological Indicators goes from six to nine. Likewise, publications like PLoS ONE, Wit Transactions On Ecology And The Environment, Energy Policy, Lecture Notes In Computer Science, Applied Energy, Energy Policy, and Ecological Economics disappear from the top 15 of publications on sustainability, while Entrepreneurship And Sustainability Issues, Advances In Intelligent Systems And Computing, Energies, Land Use Policy, Water Switzerland, and International Journal Of Environmental Research And Public Health appear in the top 15 , ranking $10,11,12,13,14$, and 15 respectively.

Table 5. Journals on sustainability between 2016 and 2020.

\begin{tabular}{ccc}
\hline Journal & Documents & $\%$ Documents \\
\hline Sustainability Switzerland & 6477 & $6.6 \%$ \\
\hline Journal Of Cleaner Production & 3269 & $3.3 \%$ \\
\hline Iop Conference Series Earth And Environmental Science & 1014 & $1.0 \%$ \\
\hline Science Of The Total Environment & 847 & $0.9 \%$ \\
\hline Iop Conference Series Materials Science And Engineering & 550 & $0.6 \%$ \\
\hline Renewable And Sustainable Energy Reviews & 456 & $0.5 \%$ \\
\hline Journal Of Environmental Management & 432 & $0.4 \%$ \\
\hline Resources Conservation And Recycling & 392 & $0.4 \%$ \\
\hline Ecological Indicators & 388 & $0.4 \%$ \\
\hline Entrepreneurship And Sustainability Issues & 387 & $0.4 \%$ \\
\hline Advances In Intelligent Systems And Computing & 340 & $0.3 \%$ \\
\hline Energies & 328 & $0.3 \%$ \\
\hline Land Use Policy & 327 & $0.3 \%$ \\
\hline Water Switzerland & 315 & $0.3 \%$ \\
\hline International Journal Of Environmental Research And Public Health & 309 & $0.3 \%$ \\
\hline
\end{tabular}

On the other hand, Table 6 shows the main authors that have gained relevance between 2016 and 2020, highlighting authors like Ren, Mbohwa, Klemeš, Streimikiene, Frantzeskaki, and Govindan; and authors like Dincer, Sarkis, Azapagic, continue to be relevant among the 10 most prominent authors in sustainability for the long and medium term. Authors like Lal, Penzenstadler, Schaltegger, and Germani have lost relevance in the number of published documents by not appearing in the top 10 for the medium term, while Geng, Streimikiene, Frantzeskaki, and Govindan appear in the top 10 for the medium term. It is noted that each author in Table 6 has published more than 40 documents on sustainability in the last 5 years. Recurrent thematic areas addressed by these authors correspond to Energy, Environmental Science, Engineering, and Business, Management and Accounting. 
Table 6. Main authors on sustainability in the last 5 years.

\begin{tabular}{|c|c|c|c|c|c|c|}
\hline Author & Scopus Author ID & Docs.* & $\begin{array}{l}\text { h-Index and } \\
\text { Citations }\end{array}$ & Main Subject Area & Affiliation & Country/Territory \\
\hline Ren, J. & 35220394000 & 54 & $\begin{array}{l}\text { h-index: } 31 \\
2924 \text { citations by } 2085 \\
\text { documents }\end{array}$ & $\begin{array}{c}\text { Energy } \\
\text { Environmental Science } \\
\text { Engineering } \\
\text { Business, Management } \\
\text { and Accounting } \\
\text { Chemical Engineering }\end{array}$ & $\begin{array}{l}\text { 2017-2020 Hong Kong } \\
\text { Polytechnic University. } \\
\text { 2015-2018 Syddansk Universitet. } \\
\text { 2012-2017 Università degli Studi } \\
\text { di Padova. }\end{array}$ & $\begin{array}{l}\text { Kowloon, Hong Kong. } \\
\text { Odense, Denmark. } \\
\text { Padua, Italy. }\end{array}$ \\
\hline Mbohwa, C. & 6603262827 & 53 & $\begin{array}{l}\text { h-index: } 17 \\
1116 \text { citations by } 988 \\
\text { documents }\end{array}$ & $\begin{array}{c}\text { Engineering } \\
\text { Business, Management } \\
\text { and Accounting } \\
\text { Decision Sciences } \\
\text { Computer Science } \\
\text { Energy }\end{array}$ & $\begin{array}{l}\text { 2009-2020 University of } \\
\text { Johannesburg, Johannesburg. } \\
2019 \text { University of Science } \\
\text { And Technology. } \\
2019 \text { University of Johannesburg. }\end{array}$ & $\begin{array}{c}\text { South Africa. } \\
\text { Botswana. } \\
\text { Johannesburg, South Africa. }\end{array}$ \\
\hline Sarkis, J. & 57194726123 & 53 & $\begin{array}{c}\text { h-index: } 81 \\
27,237 \text { citations by } \\
14,593 \text { documents }\end{array}$ & $\begin{array}{c}\text { Business, Management } \\
\text { and Accounting } \\
\text { Engineering } \\
\text { Decision Sciences } \\
\text { Environmental Science } \\
\text { Economics, Econometrics } \\
\text { and Finance }\end{array}$ & $\begin{array}{c}\text { 2013-2020 Worcester } \\
\text { Polytechnic Institute. } \\
\text { 2015-2020 Foisie Business School. } \\
\text { 2019-2020 Hanken School } \\
\text { of Economics. }\end{array}$ & $\begin{array}{l}\text { Worcester, United States. } \\
\text { Worcester, United States. } \\
\text { Helsinki, Finland. }\end{array}$ \\
\hline Azapagic, A. & 54967174100 & 50 & $\begin{array}{l}\text { h-index: } 47 \\
7650 \text { citations by } 6103 \\
\text { documents }\end{array}$ & $\begin{array}{l}\text { Environmental Science } \\
\text { Engineering } \\
\text { Energy } \\
\text { Chemical Engineering } \\
\text { Business, Management } \\
\text { and Accounting }\end{array}$ & $\begin{array}{l}\text { 2007-2020 Department of Chemical } \\
\text { Engineering and Analytical Science. } \\
\text { 2007-2020 University of Manchester. } \\
\text { 2014-2015 Brunel } \\
\text { University London. }\end{array}$ & $\begin{array}{l}\text { Manchester, United Kingdom. } \\
\text { Manchester, United Kingdom. } \\
\text { Uxbridge, United Kingdom. }\end{array}$ \\
\hline Dincer, I. & 56278550500 & 44 & $\begin{array}{l}\text { h-index: } 91 \\
\text { 36,621 citations by } \\
19,711 \text { documents }\end{array}$ & $\begin{array}{c}\text { Energy } \\
\text { Engineering } \\
\text { Physics and Astronomy } \\
\text { Environmental Science } \\
\text { Chemical Engineering }\end{array}$ & $\begin{array}{c}\text { 2003-2020 Ontario Tech University. } \\
\text { 2016-2020 Yildiz Technical } \\
\text { University. }\end{array}$ & $\begin{array}{l}\text { Oshawa, Canada. } \\
\text { Istanbul, Turkey. }\end{array}$ \\
\hline Geng, Y. & 7103277844 & 44 & $\begin{array}{l}\text { h-index: } 63 \\
\text { 13,102 citations by } \\
8577 \text { documents }\end{array}$ & $\begin{array}{l}\text { Environmental Science } \\
\text { Engineering } \\
\text { Energy } \\
\text { Business, Management } \\
\text { and Accounting } \\
\text { Social Sciences }\end{array}$ & $\begin{array}{l}\text { 2018-2020 Tongji University. } \\
\text { 2014-2020 Shanghai Jiao } \\
\text { Tong University. } \\
\text { 2019-2020 China University of } \\
\text { Mining and Technology, }\end{array}$ & $\begin{array}{l}\text { Shanghai, China. } \\
\text { Xuzhou, China. }\end{array}$ \\
\hline
\end{tabular}


Table 6. Cont

\begin{tabular}{|c|c|c|c|c|c|c|}
\hline Author & Scopus Author ID & Docs.* & $\begin{array}{l}\text { h-Index and } \\
\text { Citations }\end{array}$ & Main Subject Area & Affiliation & Country/Territory \\
\hline Klemeš, J.J. & 56903012000 & 42 & $\begin{array}{l}\text { h-index: } 54 \\
\text { 10,746 citations by } \\
6098 \text { documents }\end{array}$ & $\begin{array}{c}\text { Engineering } \\
\text { Environmental Science } \\
\text { Chemical } \\
\text { Engineering } \\
\text { Energy }\end{array}$ & $\begin{array}{l}\text { 2017-2020 Brno University } \\
\text { of Technology. } \\
2019 \text { Islamic Azad University. }\end{array}$ & $\begin{array}{l}\text { Brno, Czech Republic. } \\
\text { Tehran, Iran. }\end{array}$ \\
\hline Streimikiene, D. & 57195415199 & 42 & $\begin{array}{l}\text { h-index: } 26 \\
3126 \text { citations by } 2483 \\
\text { documents }\end{array}$ & $\begin{array}{c}\text { Energy } \\
\text { Social Sciences } \\
\text { Business, Management } \\
\text { and Accounting } \\
\text { Economics, Econometrics } \\
\text { and Finance } \\
\text { Environmental Science }\end{array}$ & $\begin{array}{l}\text { 2005-2020 Lithuanian } \\
\text { Energy Institute. } \\
\text { 2005-2020 Vilniaus universitetas. } \\
\text { 2014-2020 Lithuanian } \\
\text { Sports University. }\end{array}$ & $\begin{array}{l}\text { Kaunas, Lithuania. } \\
\text { Vilnius, Lithuania. } \\
\text { Kaunas, Lithuania. }\end{array}$ \\
\hline Frantzeskaki, N. & 7801567129 & 41 & $\begin{array}{l}\text { h-index: } 31 \\
3514 \text { citations by } 2654 \\
\text { documents }\end{array}$ & $\begin{array}{c}\text { Environmental Science } \\
\text { Social Sciences } \\
\text { Business, Management } \\
\text { and Accounting } \\
\text { Energy } \\
\text { Agricultural and Biological } \\
\text { Sciences }\end{array}$ & $\begin{array}{l}\text { 2019-2020 Swinburne University } \\
\text { of Technology. } \\
\text { 2010-2020 Erasmus } \\
\text { Universiteit Rotterdam. } \\
\text { 2013-2014 Dutch Research Institute } \\
\text { for Transitions DRIFT. }\end{array}$ & $\begin{array}{l}\text { Melbourne, Australia. } \\
\text { Rotterdam, Netherlands }\end{array}$ \\
\hline Govindan, K. & 54986334000 & 41 & $\begin{array}{l}\text { h-index: } 72 \\
16,170 \text { citations by } \\
9374 \text { documents }\end{array}$ & $\begin{array}{c}\text { Engineering } \\
\text { Business, Management } \\
\text { and Accounting } \\
\text { Decision Sciences } \\
\text { Environmental Science } \\
\text { Energy }\end{array}$ & $\begin{array}{l}\text { 2008-2020 Syddansk Universitet. } \\
\text { 2020 Shanghai Maritime University. } \\
2020 \text { Asia University Taiwan. }\end{array}$ & $\begin{array}{l}\text { Odense, Denmark. } \\
\text { Shanghai, China. } \\
\text { Wufong, Taiwan. }\end{array}$ \\
\hline
\end{tabular}

* Documents published in Scopus in 2011-2020 related to sustainability. 
Figure 4 illustrates the 20 countries and territories with the largest number of studies related to sustainability, highlighting that the United States, United Kingdom, and China continue as leading countries, contributing $26.8 \%$ of the scientific production between 2016 and 2020 . When comparing Figure 2 with Figure 4, it is deduced that Italy, India, and Indonesia improved their position in scientific production in the medium term, while Australia, Germany, Canada, South Africa, Portugal, Japan, Turkey, and Switzerland reduced its position compared to other countries and territories. Likewise, South Korea appears in the last 5 years as one of the leading countries in the scientific production of sustainability.

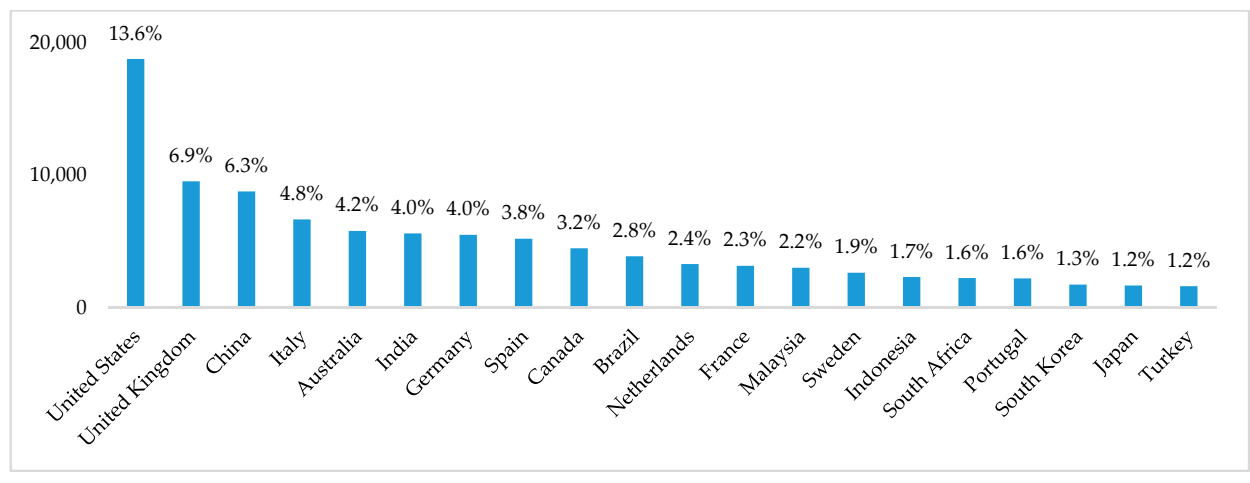

Figure 4. Articles published on sustainability between 2016 and 2020.

The documents with the most significant impact on citations between 2016 and 2020 are described in Table 7, reflecting citations ranging on average from 96 to 458 citations per year for each document. Among these documents are those of Bejan [41] and Ong et al. [42] that were among the 10 most cited articles in the long term (Table 4). The topics addressed by these documents are also interdisciplinary, including engineering, chemistry, materials science, technologies, circular economy, collaborative consumption, natural resources, and agriculture.

Table 7. Most cited documents in 2016-2020.

\begin{tabular}{|c|c|c|c|}
\hline Document Title & Topics & Authors & Cites \\
\hline $\begin{array}{l}\text { Advanced Engineering } \\
\text { Thermodynamics }\end{array}$ & $\begin{array}{l}\text { A book that bridges the gap between engineering } \\
\text { applications and the first and second laws of } \\
\text { thermodynamics, describing real-world applications of } \\
\text { thermodynamics concepts, including solar energy, } \\
\text { refrigeration, air conditioning, thermofluid design, chemical } \\
\text { design, constructal design, and more, linking new } \\
\text { technologies in sustainability to fundamental } \\
\text { thermodynamics concepts. }\end{array}$ & [41] & 2290 \\
\hline $\begin{array}{l}\text { Graphitic Carbon Nitride } \\
\text { (g-C3 N4)-Based Photocatalysts } \\
\text { for Artificial Photosynthesis and } \\
\text { Environmental Remediation: } \\
\text { Are We a Step Closer to } \\
\text { Achieving Sustainability? }\end{array}$ & $\begin{array}{l}\text { A review summarizing a panorama of the latest progress } \\
\text { related to the design and construction of pristine g-C3N4 } \\
\text { (Graphitic carbon nitride) and g-C3N4-based } \\
\text { nanocomposites. This review can stimulate new research for } \\
\text { the development of a sustainable future without } \\
\text { environmental detriment. }\end{array}$ & [42] & 2194 \\
\hline $\begin{array}{l}\text { Sodium-ion batteries: } \\
\text { Present and future }\end{array}$ & $\begin{array}{l}\text { The article summarizes and discuss current research on } \\
\text { materials and propose future directions for Sodium-ion } \\
\text { batteries (SIBs) to provide important insights into scientific } \\
\text { and practical issues in the development of SIBs. }\end{array}$ & [47] & 1101 \\
\hline $\begin{array}{l}\text { Next generation } 5 G \\
\text { wireless networks: } \\
\text { A comprehensive survey }\end{array}$ & $\begin{array}{l}\text { Authors make an exhaustive review of wireless evolution } \\
\text { toward 5G networks. They discuss the new architectural } \\
\text { changes associated with the radio access network } \\
\text { (RAN) design, make an in-depth survey of underlying novel } \\
\text { mm-wave physical layer technologies, look into the killer } \\
\text { applications, considered as the major driving force } \\
\text { behind 5G, and point out major existing research issues and } \\
\text { identify possible future research directions. }\end{array}$ & [48] & 956 \\
\hline
\end{tabular}


Table 7. Cont.

\begin{tabular}{|c|c|c|c|}
\hline Document Title & Topics & Authors & Cites \\
\hline $\begin{array}{l}\text { A review on circular economy: } \\
\text { The expected transition to a } \\
\text { balanced interplay of } \\
\text { environmental and } \\
\text { economic systems }\end{array}$ & $\begin{array}{l}\text { A study providing an extensive review of the literature of } \\
\text { last two decades about circular economy, with the purpose } \\
\text { of grasping the main } C E \text { features and perspectives: origins, } \\
\text { basic principles, advantages and disadvantages, modelling } \\
\text { and implementation of } C E \text { at the different levels worldwide. }\end{array}$ & [49] & 880 \\
\hline $\begin{array}{l}\text { The sharing economy: } \\
\text { Why people participate in } \\
\text { collaborative consumption }\end{array}$ & $\begin{array}{l}\text { An article investigating people's motivations to participate } \\
\text { in Collaborative Consumption (CC), showing that } \\
\text { participation in CC is motivated by many factors such as its } \\
\text { sustainability, enjoyment of the activity as well as } \\
\text { economic gains. }\end{array}$ & [50] & 774 \\
\hline $\begin{array}{l}\text { Advances in Synthetic } \\
\text { Applications of Hypervalent } \\
\text { Iodine Compounds }\end{array}$ & $\begin{array}{l}\text { A review about the benefits of using hypervalent iodine } \\
\text { compounds as an environmentally sustainable alternative } \\
\text { to heavy metals. }\end{array}$ & [51] & 725 \\
\hline $\begin{array}{l}\text { Sustainability: Four billion } \\
\text { people facing severe } \\
\text { water scarcity }\end{array}$ & $\begin{array}{l}\text { Authors assess blue water scarcity globally at a high spatial } \\
\text { resolution on a monthly basis, finding that two-thirds of the } \\
\text { global population live under conditions of severe water } \\
\text { scarcity at least } 1 \text { month of the year. To reduce the threat } \\
\text { posed by water scarcity, authors propose to put caps to water } \\
\text { consumption by river basin, increase water-use efficiencies, } \\
\text { and better sharing of the limited freshwater resources. }\end{array}$ & [52] & 710 \\
\hline $\begin{array}{l}\text { Abiotic Stress Signaling and } \\
\text { Responses in Plants }\end{array}$ & $\begin{array}{l}\text { A study analyzing abiotic stress signaling and responses to } \\
\text { improve stress resistance in crops to achieve agricultural } \\
\text { sustainability and food security for a growing } \\
\text { world population. }\end{array}$ & [53] & 706 \\
\hline $\begin{array}{l}\text { The Circular Economy-A new } \\
\text { sustainability paradigm? }\end{array}$ & $\begin{array}{l}\text { An extensive literature review addressing the relationship } \\
\text { between circular economy and sustainability to provide } \\
\text { conceptual clarity by distinguishing the terms and } \\
\text { synthesizing the similarities, differences and relationships } \\
\text { between both terms. }\end{array}$ & [54] & 677 \\
\hline
\end{tabular}

The 20 most relevant research topics between 2016 and 2020 are presented in Figure 5, indicating that sustainable development and humans continue as the leading topics, while decision-making, China, women, procedures, agriculture, and men increased the importance with respect to the results of Figure 3. Likewise, topics like United States and energy use have lost the most relevance when comparing the periods 2011-2020 and 2016-2020. Indeed, topics like innovation and carbon dioxide are no longer among the 20 most relevant topics of sustainability and are replaced by topics such as controlled studies, and adults.

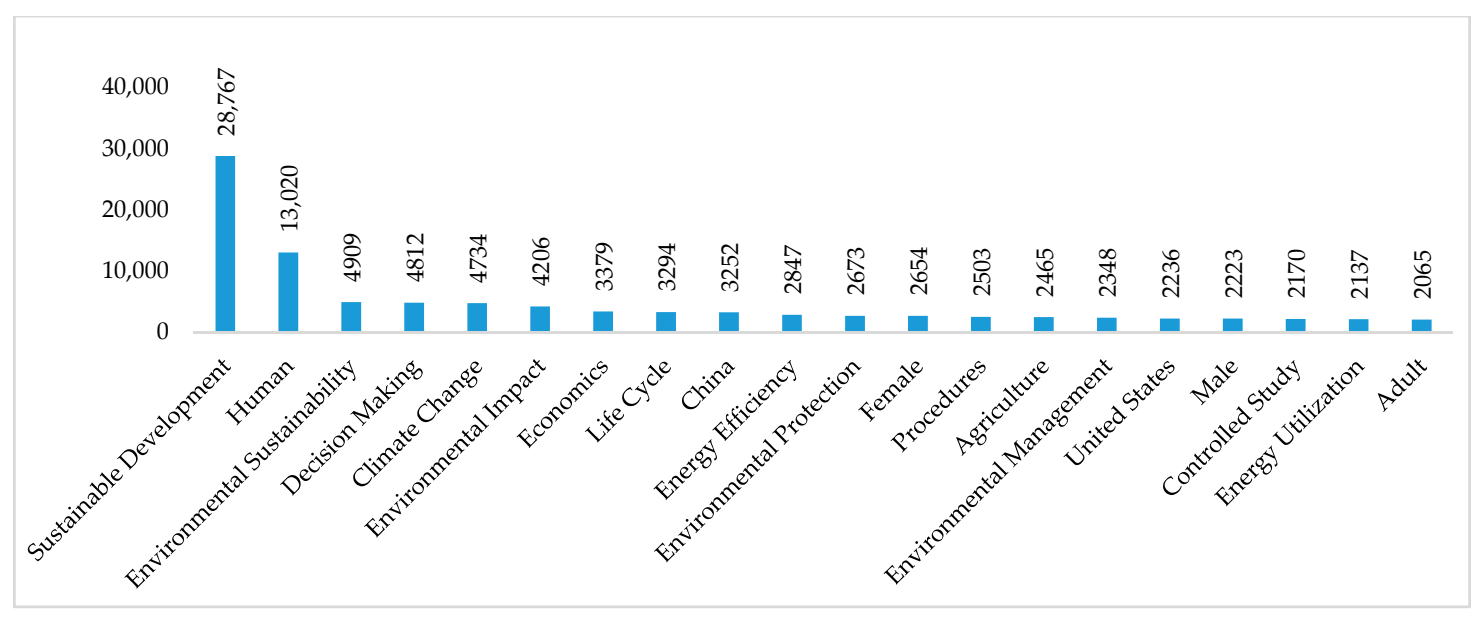

Figure 5. Research topics on sustainability between 2016 and 2020. 


\subsection{Research on Sustainability in the Short Term (2 Years)}

Regarding the short-term analysis, in this period $17.2 \%$ of publications on sustainability have been generated, which is equivalent to 37,512 documents, highlighting the relevance of sustainability in the literature in subject areas like environmental sciences, social sciences, engineering, energy, business, management and accounting, biological and agricultural sciences, computer science, economics and finance, medicine, earth sciences, and materials sciences, which were equally relevant to the analysis for large and medium term.

According to Table 8, the journals and publications with the largest number of articles published on sustainability in the short term are Sustainability Switzerland, Journal Of Cleaner Production, Iop Conference Series Earth And Environmental Science, Science Of The Total Environment, and Iop Conference Series Materials Science And Engineering, corresponding to $17.0 \%$ of publications in the short term on sustainability. In contrast to the publications shown in Table 5, the journals Environment Development And Sustainability and Environmental Science And Pollution Research appear in positions 12 and 13 respectively for the short term, while Renewable And Sustainable Energy Reviews and Land Use Policy disappear from this list, ranking 19 and 24 respectively on the date of this study.

Table 8. Journals on sustainability between 2019 and 2020.

\begin{tabular}{ccc}
\hline Journal & Documents & $\%$ Documents \\
\hline Sustainability Switzerland & 3457 & $9.2 \%$ \\
\hline Journal Of Cleaner Production & 1421 & $3.8 \%$ \\
\hline Iop Conference Series Earth And Environmental Science & 697 & $1.9 \%$ \\
\hline Science Of The Total Environment & 508 & $1.4 \%$ \\
\hline Iop Conference Series Materials Science And Engineering & 304 & $0.8 \%$ \\
\hline Journal Of Environmental Management & 230 & $0.6 \%$ \\
\hline Entrepreneurship And Sustainability Issues & 229 & $0.6 \%$ \\
\hline Advances In Intelligent Systems And Computing & 227 & $0.6 \%$ \\
\hline Resources Conservation And Recycling & 208 & $0.6 \%$ \\
\hline Energies & 196 & $0.5 \%$ \\
\hline International Journal Of Environmental Research And Public Health & 196 & $0.5 \%$ \\
\hline Environment Development And Sustainability & 192 & $0.5 \%$ \\
\hline Environmental Science And Pollution Research & 164 & $0.4 \%$ \\
\hline Ecological Indicators & 153 & $0.4 \%$ \\
\hline Water Switzerland & 145 & $0.4 \%$ \\
\hline
\end{tabular}

On the other hand, Table 9 shows the authors with the largest number of documents published in the short term, highlighting that Mbohwa, Sarkis, Azapagic, Klemeš, and Streimikiene belong to the top 10 both for the medium and the short term. It is also identified that Streimikiene, Jermsittiparsert, Azapagic, Sarkis, Tsang, Alola, and Fu present 20 or more documents between 2019 and May 2020. Likewise, the recurrent areas in the authors from Table 9 correspond to Environmental Science, Engineering, Energy, and Business, Management and Accounting. 
Table 9. Main authors in sustainability in the short term.

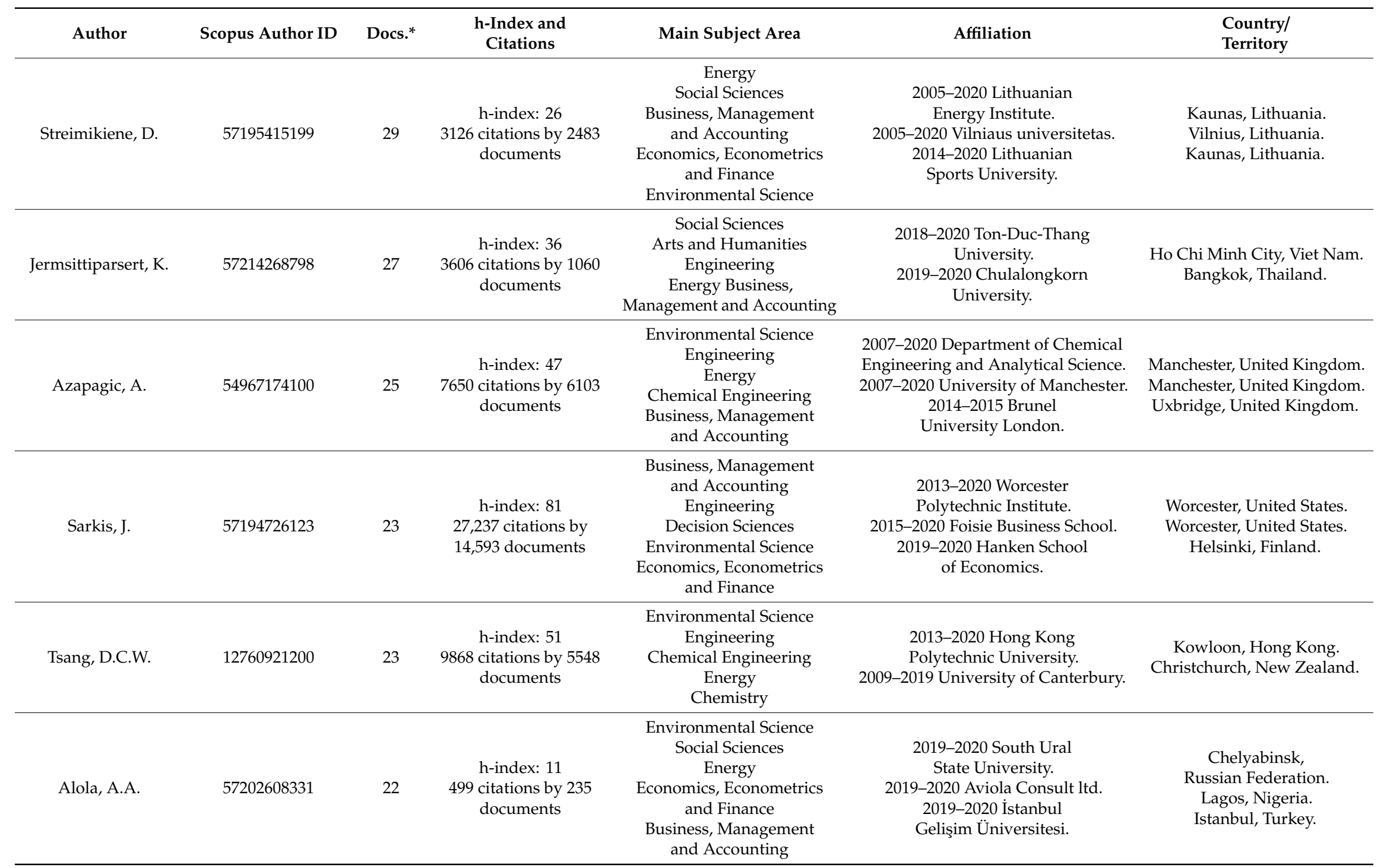


Table 9. Cont.

\begin{tabular}{|c|c|c|c|c|c|c|}
\hline Author & Scopus Author ID & Docs.* & $\begin{array}{l}\text { h-Index and } \\
\text { Citations }\end{array}$ & Main Subject Area & Affiliation & $\begin{array}{l}\text { Country/ } \\
\text { Territory }\end{array}$ \\
\hline $\mathrm{Fu}, \mathrm{B}$. & 23004373400 & 20 & $\begin{array}{c}\text { h-index: } 65 \\
\text { 16,383 citations by } \\
10,586 \text { documents }\end{array}$ & $\begin{array}{c}\text { Environmental Science } \\
\text { Agricultural and } \\
\text { Biological Sciences } \\
\text { Earth and Planetary Sciences } \\
\text { Social Sciences } \\
\text { Multidisciplinary }\end{array}$ & $\begin{array}{l}\text { 2007-2020 Beijing Normal University. } \\
\text { 1994-2020 Chinese Academy } \\
\text { of Sciences. } \\
\text { 1991-2020 Research Center for } \\
\text { Eco-Environmental Sciences Chinese } \\
\text { Academy of Sciences. }\end{array}$ & Beijing, China. \\
\hline Tseng, M.L. & 44261803600 & 19 & $\begin{array}{c}\text { h-index: } 40 \\
4945 \text { citations by } 3398 \\
\text { documents }\end{array}$ & $\begin{array}{c}\text { Environmental Science } \\
\text { Business, Management } \\
\text { and Accounting } \\
\text { Engineering } \\
\text { Energy } \\
\text { Computer Science }\end{array}$ & $\begin{array}{l}\text { 2018-2020 Asia University Taiwan. } \\
\text { 2019-2020 China Medical } \\
\text { University Taichung. }\end{array}$ & $\begin{array}{l}\text { Wufong, Taiwan. } \\
\text { Taichung, Taiwan. }\end{array}$ \\
\hline Klemeš, J.J. & 56903012000 & 18 & $\begin{array}{c}\text { h-index: } 54 \\
\text { 10,746 citations by } \\
6098 \text { documents }\end{array}$ & $\begin{array}{c}\text { Engineering } \\
\text { Environmental Science } \\
\text { Chemical } \\
\text { Engineering } \\
\text { Energy }\end{array}$ & $\begin{array}{l}\text { 2017-2020 Brno University } \\
\text { of Technology. } \\
2019 \text { Islamic Azad University. }\end{array}$ & $\begin{array}{c}\text { Brno, Czech Republic. } \\
\text { Tehran, Iran. }\end{array}$ \\
\hline Mbohwa, C. & 6603262827 & 17 & $\begin{array}{l}\text { h-index: } 17 \\
1116 \text { citations by } 988 \\
\text { documents }\end{array}$ & $\begin{array}{c}\text { Engineering } \\
\text { Business, Management } \\
\text { and Accounting } \\
\text { Decision Sciences } \\
\text { Computer Science } \\
\text { Energy }\end{array}$ & $\begin{array}{l}\text { 2009-2020 University of } \\
\text { Johannesburg, Johannesburg. } \\
2019 \text { University of Science } \\
\text { And Technology. } \\
2019 \text { University of Johannesburg. }\end{array}$ & $\begin{array}{c}\text { South Africa. } \\
\text { Botswana. } \\
\text { Johannesburg, South Africa. }\end{array}$ \\
\hline
\end{tabular}

* Documents published in Scopus in 2019-2020 related to sustainability. 
Regarding the analysis by territories, Figure 6 shows that the United States, China and the United Kingdom dominate the scientific production related to sustainability by contributing $25.6 \%$ of the world's scientific production in the short term. When comparing Figure 6 with Figure 4, countries like China, India, Spain, Malaysia, Indonesia, and Portugal improved their position in scientific production in the short term, while the United Kingdom, Australia, Germany, the Netherlands, and South Africa worsened its position when comparing to the medium term. Likewise, Russia appears in the short term as one of the leading countries in scientific production on sustainability.

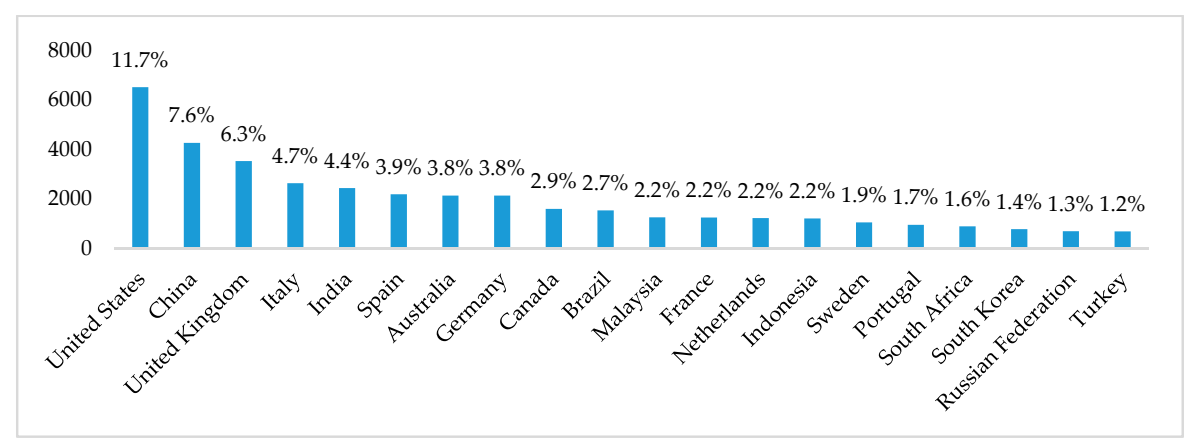

Figure 6. Articles published on sustainability between 2019 and 2020.

Analyzing the impact of publications in the short term, Table 10 lists the most cited articles addressing sustainability, reflecting from 97 to 548 citations per document between 2019 and 2020 . The document of Willett et al. [55] obtained the highest citation addressing a universal healthy diet of reference to increase the achievement of SDGs. The topics addressed by the other documents include areas of knowledge of energy, economics, natural resources, technologies, ecological footprint, agriculture, and climate change.

Table 10. Most cited documents in 2019-2020.

\begin{tabular}{|c|c|c|c|}
\hline Document Title & Topics & Authors & Cites \\
\hline $\begin{array}{l}\text { Food in the Anthropocene: } \\
\text { the EAT-Lancet Commission on } \\
\text { healthy diets from sustainable } \\
\text { food systems }\end{array}$ & $\begin{array}{c}\text { A framework to describe a universal healthy reference diet, } \\
\text { based on an increase in consumption of healthy foods, and a } \\
\text { decrease in consumption of unhealthy foods that would } \\
\text { provide major health benefits, and also increase the } \\
\text { likelihood of attainment of the Sustainable } \\
\text { Development Goals. }\end{array}$ & [55] & 548 \\
\hline $\begin{array}{l}\text { Toward a sustainable } \\
\text { environment: Nexus between } \\
\mathrm{CO}_{2} \text { emissions, resource rent, } \\
\text { renewable and nonrenewable } \\
\text { energy in 16-EU countries }\end{array}$ & $\begin{array}{l}\text { The study investigates the long-run and causal interaction } \\
\text { between, renewable energy consumption, nonrenewable } \\
\text { energy consumption, and economic growth in a carbon } \\
\text { function. The study reveals a feedback mechanism between } \\
\text { economic growth, renewable, and nonrenewable energy } \\
\text { consumption; and a feedback causality between natural } \\
\text { resources rent and economic growth. }\end{array}$ & [56] & 135 \\
\hline $\begin{array}{l}\text { An enhanced extreme learning } \\
\text { machine model for river flow } \\
\text { forecasting: State-of-the-art, } \\
\text { practical applications in water } \\
\text { resource engineering area and } \\
\text { future research direction }\end{array}$ & $\begin{array}{l}\text { This paper investigates the viability of the enhanced version } \\
\text { of extreme learning machine (EELM) model in river flow } \\
\text { forecasting applied in a tropical environment. The model } \\
\text { can be embraced practically in real-life water resources } \\
\text { management and river sustainability decisions. }\end{array}$ & {$[57]$} & 121 \\
\hline $\begin{array}{l}\text { Blockchain technology and its } \\
\text { relationships to sustainable } \\
\text { supply chain management }\end{array}$ & $\begin{array}{c}\text { Authors examine the blockchain technology and smart } \\
\text { contracts with potential application to supply chain } \\
\text { management, and investigate how blockchain can address } \\
\text { and aid supply chain sustainability. The study } \\
\text { introducesblockchain technology adoption barriers } \\
\text { categories, and proposes future research propositions and } \\
\text { directions that can provide insights into overcoming barriers } \\
\text { and adoption of blockchain technology for supply } \\
\text { chain management. }\end{array}$ & [58] & 117 \\
\hline
\end{tabular}


Table 10. Cont.

\begin{tabular}{|c|c|c|c|}
\hline Document Title & Topics & Authors & Cites \\
\hline $\begin{array}{l}\text { Sustainable technologies for } \\
\text { water purification from heavy } \\
\text { metals: review and analysis }\end{array}$ & $\begin{array}{l}\text { A review of the current state-of-the-art of available } \\
\text { technologies for water purification and heavy metal ion } \\
\text { removal, as heavy metal ions are the most harmful and } \\
\text { widespread contaminants. Authors introduce a compact } \\
\text { index, the Ranking Efficiency Product (REP), to evaluate the } \\
\text { efficiency and ease of implementation of the various } \\
\text { technologies in this perspective. }\end{array}$ & [59] & 104 \\
\hline $\begin{array}{l}\text { Investigation of environmental } \\
\text { Kuznets curve for ecological } \\
\text { footprint: The role of energy and } \\
\text { financial development }\end{array}$ & $\begin{array}{l}\text { A study that examines the validity of environmental } \\
\text { Kuznets curve hypothesis by investigating the relationship } \\
\text { between economic growth, energy consumption, financial } \\
\text { development, and ecological footprint for the period from } \\
1977 \text { to } 2013 \text { in } 11 \text { newly industrialized countries. Authors } \\
\text { conclude that there is bi-directional causality between } \\
\text { economic growth and ecological footprint. }\end{array}$ & [60] & 103 \\
\hline $\begin{array}{l}\text { Environmental sustainability } \\
\text { and its growth in Malaysia by } \\
\text { elaborating the green economy } \\
\text { and environmental efficiency }\end{array}$ & $\begin{array}{l}\text { This investigation tries to find the condition of knowledge in } \\
\text { Malaysia on the green economy. The result shows that an } \\
\text { expansion in the prioritizing green economy anticipated by } \\
\text { the companies working in Malaysia will prompt increment } \\
\text { in green monetary sustainability and } \\
\text { environmental sustainability. }\end{array}$ & [61] & 103 \\
\hline $\begin{array}{l}\text { An agenda for sustainability } \\
\text { transitions research: State of the } \\
\text { art and future directions }\end{array}$ & $\begin{array}{l}\text { The article provides an extensive review and an updated } \\
\text { research agenda for sustainability transitions, classified into } \\
\text { nine main themes: understanding transitions; power, agency } \\
\text { and politics; governing transitions; civil society, culture and } \\
\text { social movements; businesses and industries; transitions in } \\
\text { practice and everyday life; geography of transitions; } \\
\text { ethical aspects; and methodologies. }\end{array}$ & [62] & 100 \\
\hline $\begin{array}{l}\text { The global burden of pathogens } \\
\text { and pests on major food crops }\end{array}$ & $\begin{array}{l}\text { Authors present an assessment of crop health, and provide } \\
\text { numerical estimates of yield losses on an individual } \\
\text { pathogen and pest basis for five major crops globally and in } \\
\text { food security hotspots. The analysis contributes critical } \\
\text { information to prioritize crop health management to } \\
\text { improve the sustainability of agroecosystems in delivering } \\
\text { services to societies. }\end{array}$ & [63] & 97 \\
\hline $\begin{array}{l}\text { The global tree } \\
\text { restoration potential }\end{array}$ & $\begin{array}{c}\text { The study mapped the global potential tree coverage and } \\
\text { highlights global tree restoration as the most effective } \\
\text { climate change solution to date and the urgent need } \\
\text { for action. }\end{array}$ & [64] & 97 \\
\hline
\end{tabular}

In the short term, Figure 7 shows that research topics like sustainable development and humans continue to lead in the area of sustainability, while topics like Climate Change, China, Women, Controlled Studies, Adults, and Men increase their importance with respect to the medium term. Similarly, the topics of Procedures, United States, and Energy Use are no longer among the most relevant topics on sustainability and are replaced by topics like Non-human, Recycling, and Economic and Social Effects.

\subsection{Research on Sustainability and Open Innovation}

As shown in Figure 8, 227 documents on sustainability and open innovation were identified in Scopus between 1997 and 2020. From the first publication in 1997, it took 10 years (2007) for other documents on this topic to be published, and only until 2013 a considerable increase in the number of published documents appeared. Several documents were published in 2016-2020 (67.4\%), and 45.8\% of the documents in this topic were published in the short term, between 2019 and 2020. This indicates that sustainability with open innovation represents a topic that has been gaining interest in the recent years. 


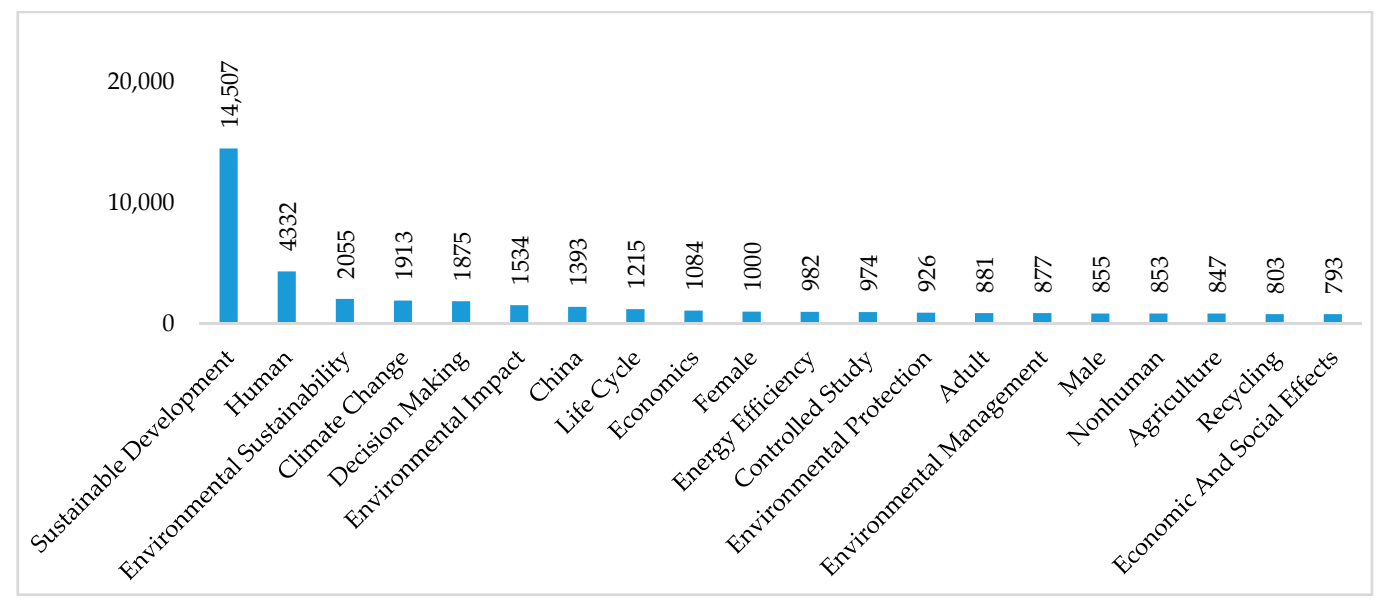

Figure 7. Research topics on sustainability between 2019 and 2020.

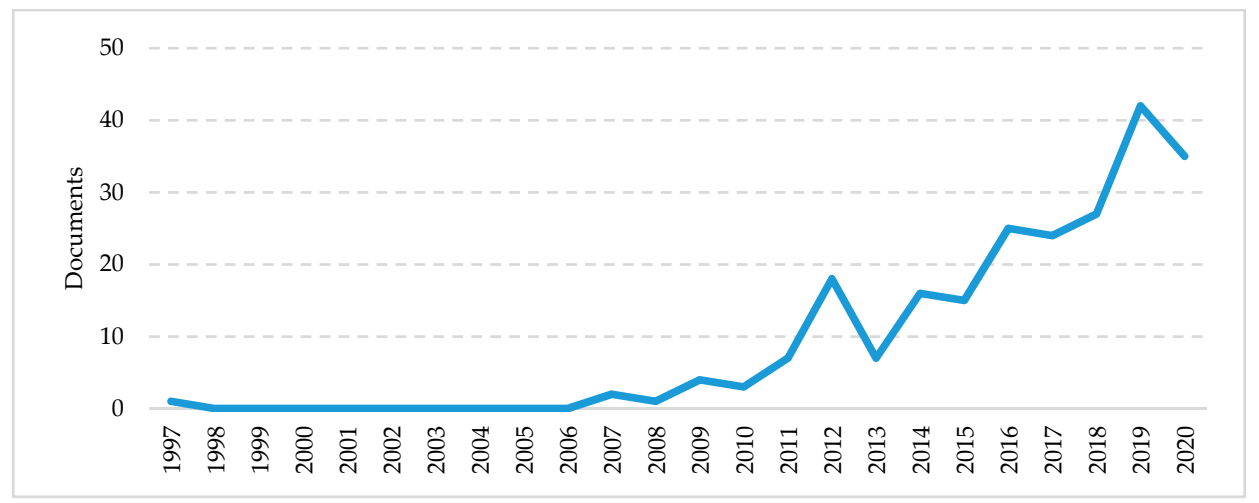

Figure 8. Documents published on sustainability and open innovation between 1997 and 2020 .

Figure 9 shows the leading authors on sustainability and open innovation, highlighting Park and Yun as the authors with most documents in this topic. These authors have made conceptual models and dynamic systems applied to the macroeconomic, collaborative economy, and electronic commerce fields, all considering some component of sustainability.

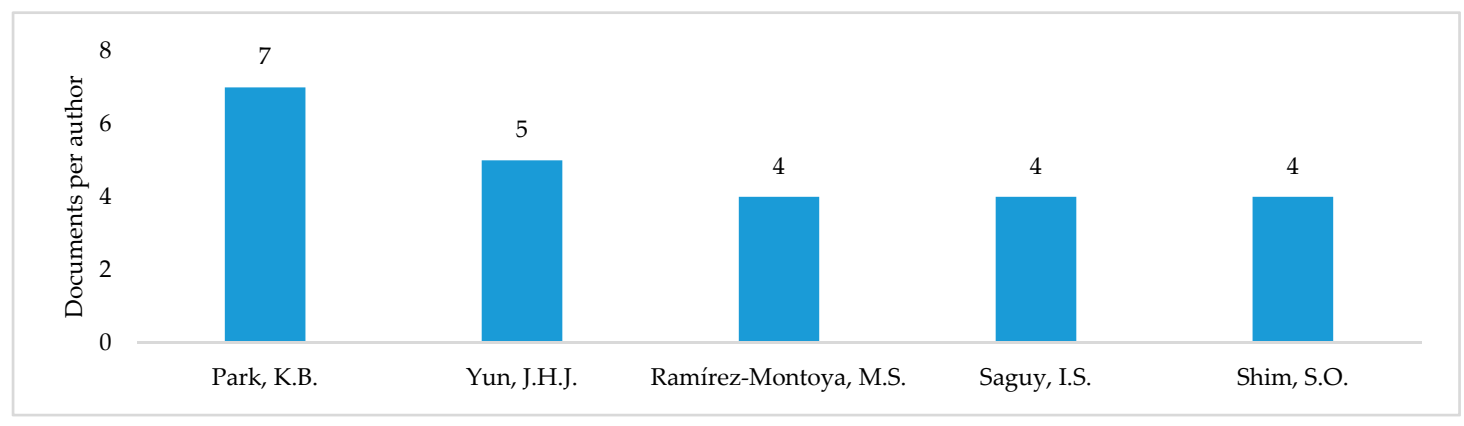

Figure 9. Leading authors on sustainability and open innovation.

The search process distinguishes open innovation dynamics, micro and macro open innovation dynamics, and open innovation engineering as the main working lines on sustainability with open innovation. Regarding open innovation dynamics, Yun et al. [65] proposed a system dynamics model to relate open innovation as one of the determinants of economic growth, and for this, they include in three sub-economies: open innovation (led by SMEs and start-ups), the closed open innovation (led by large companies) and social innovation. Yun et al. [66] performed a study to establish the incidence of 
open innovation strategies in the dynamics of the business models of three collaborative economy companies in the car-sharing sector. Yun et al. [67] analyzed the dynamics of open innovation through a case study of Alibaba company (B2B platform) from 1997 to 2017, finding that Alibaba has adopted models of creative and global e-commerce business through open innovation and an open culture conducive to innovation.

Regarding micro and macro open innovation dynamics, Yun and Liu [23] performed an extensive literature review to generate a conceptual model of open innovation, closed open innovation, and social innovation subsystems, which represent an alternative to the achievement of economic, social, and environmental sustainability. In this model, industries adopt open platforms to maintain innovation; universities increasingly participate in co-creation and technology transfer activities; governments changed from regulation control toward facilitation, and the society is increasingly interested in a collaborative economy and new R\&D concepts. Concerning open innovation engineering, Yun et al. [68] proposed a conceptual model of open innovation engineering, which is supported by a literature review to show the expansion paths of open innovation and new business models that can be triggered from engineering.

\section{Discussion}

This section presents the discussions around the general topic of sustainability and the relationship between sustainability and open innovation.

\subsection{Sustainability}

The bibliometric analysis demonstrates an exponential growth in scientific production on sustainability from 2004, the year since which $93.3 \%$ of the sustainability literature has been generated. Regarding the last 10, 5, and 2 years, statistics show that in the literature, $74.9 \%, 44.7 \%$, and $17.2 \%$ of the total sustainability documents have been generated respectively, indicating once again the importance and relevance of this field of research in the scientific and academic community in recent years. Specifically, the most relevant thematic areas of sustainability in the long, medium, and short term correspond to environmental sciences, social sciences, engineering, energy, business, management and accounting, and biological and agricultural sciences, indicating that sustainability represents a transdisciplinary (covers several disciplines transversely, including the triple bottom line to satisfy the current and future needs of society) and interdisciplinary (combines and integrates several areas of knowledge, implying the synergy between them to add value to the object of study) field of knowledge.

Similarly, the most relevant documents (with the highest citation index) for the long, medium, and short term address issues related to the environment, agricultural sciences, energy, engineering, chemistry, materials science, food, corporate social responsibility, technologies, economics, natural resources, and climate change, demonstrating the broad range of disciplines addressed by sustainability and contributing to sustainable development. Authors like Dincer, Sarkis, and Azapagic stand out for belonging to the top 10 of the authors with the most considerable number of publications on sustainability in the long and medium term, and similarly, Mbohwa, Sarkis, Azapagic, Klemeš, and Streimikiene are identified as the most influential authors on sustainability in the medium and short term. In general, the most productive authors on sustainability publications in the long, medium, and short term address issues related to Engineering, Energy, Environmental Science, and Business, Management, and Accounting.

Additionally, women like Azapagic, Penzenstadler, Streimikiene, and Frantzeskakide stand out among the most influential authors in the periods analyzed. Of these female authors, Azapagic has prevailed among the main authors in sustainability in the large, medium, and short term, performing in engineering for sustainable development, sustainable technology, life cycle assessment, and carbon footprinting. Penzenstadler stands out as one of the most relevant authors in the long term and her work focuses on environmental sustainability in software engineering and computer science. Streimikiene is an expert on sustainable energy development, sustainability assessment, and climate 
change mitigation policies, and is one of the authors with the largest production in sustainability in the medium and short term. Frantzeskaki stands out as one of the authors with the largest scientific production in the short term, and her main publications are related to environmental governance, and urban sustainability transitions. This shows that women maintain an important participation in the scientific production of sustainability in the long, medium, and short term, and it is expected to increase because of the interdisciplinary and multidisciplinary scope of sustainability and the growth of participation of women worldwide in scientific production in diverse areas of knowledge [69-71].

Delving into the role of women in sustainability, the bibliometric analysis indicates that the documents addressing topics of sustainability and women/woman/female for the long, medium, and short term are directly related to research topics like age (child, adolescent, young adult, adults, middle aged, aged), gender, male, pregnancy, controlled studies, major clinical studies, organization and management, education, women's status, economics, health care delivery, psychology, empowerment, and human experiment. For the short term, relationships with topics of climate change, leadership, and perception are identified. This shows that research in sustainability and women is primarily focused on studies related to women's life stages, clinical studies, pregnancy, and midwifery, leadership and empowerment in organizations and businesses, and their role in the economy. Consequently, the journals that contribute the most publications on sustainability and women are PLoS ONE (interdisciplinary research in natural sciences, medical research, engineering, social sciences and humanities), BMC Public Health (epidemiology of disease and public health), Women And Birth (all matters that affect women and birth, from pre-conceptual counselling, through pregnancy, birth, and the first six weeks postnatal), BMJ Open (clinical medicine, public health and epidemiology), Midwifery (pregnancy, birth, and maternity care for childbearing women, their babies and families), and International Journal Of Environmental Research And Public Health (interdisciplinary research in environmental health sciences and public health). Moreover, the territories that contribute the most research documents on sustainability and women in the long, medium, and short term are the United States and United Kingdom, highlighting that United States in each period generates more than twice the scientific production of the United Kingdom. Other countries that contribute a significant number of publications are India, Australia, Canada, Spain, and South Africa.

Returning to the general bibliometric analysis on sustainability, the analysis of principal territories and countries in publications leads us to identify that the United States is the leader in the long, medium, and short term, followed by the United Kingdom and China. Other countries with significant rates of publications belong to North America, Europe, Asia, Oceania, and South America. Regarding the most influential sustainability journals, Sustainability Switzerland and Journal Of Cleaner Production represent the leading journals because of the considerable number of published articles on sustainability, which is caused by the scope of these journals focused on interdisciplinary and transdisciplinary approaches. Followed by these, Iop Conference Series Earth And Environmental contributes significantly to the number of published documents on sustainability as it is a publication compiling proceedings papers from multiple conferences related to Earth and Environmental Science; and Science Of The Total Environment is ranked as the fourth publication with the largest number of documents being a multidisciplinary journal focused on research on the total environment. Therefore, the most influential journals in sustainability are usually transdisciplinary, interdisciplinary, and multidisciplinary publications, which are in line with the concept of sustainability that encompasses multiple disciplines and relates them to each other to pursue the same objectives.

Concerning keywords denoting the most relevant research topics on sustainability, Figure 10 highlights that sustainable development, humans, and environmental sustainability have remained as the three most important topics related to sustainability, as they are addressed by the largest number of documents in the literature. Climate change and decision-making issues have been disputed for fourth and fifth place in the periods analyzed. It is also noteworthy that the environmental impact and life cycle have retained, respectively, sixth and eighth place of relevance in the periods analyzed, while the issue of economics falls two places in the short term. On the other hand, the issue of China 
has grown in importance in the last 10 years ranking in the short term as the seventh most relevant issue on sustainability, also supported by China being one of the three countries generating the largest number of sustainability documents in the literature.

\begin{tabular}{|c|c|c|}
\hline 10 years & 5 years & 2 years \\
\hline Sustainable Development $(47,247)$ & \begin{tabular}{|l} 
Sustainable Development $(28,767)$ \\
\end{tabular} & Sustainable Development $(14,507)$ \\
\hline Human(s) $(21,764)$ & Human(s) (8061) & Human (4332) \\
\hline Environmental Sustainability (7931) & Environmental Sustainability (4909) & Environmental Sustainability (2055) \\
\hline Climate Change (7576) & Decision Making (4812) & Climate Change (1913) \\
\hline Decision Making (7205) & Climate Change (4734) & Decision Making (1875) \\
\hline Environmental Impact (7019) & Environmental Impact (4206) & Environmental Impact (1534) \\
\hline Economics (5757) & Economics (3379) & China (1393) \\
\hline Life Cycle (5227) & Life Cycle (3294) & Life Cycle (1215) \\
\hline Energy Efficiency (4869) & China (3252) & Economics (1084) \\
\hline China (4818) & Energy Efficiency (2847) & Female (1000) \\
\hline Environmental Protection (4627) & Environmental Protection (2673) & Energy Efficiency (982) \\
\hline United States (4365) & Female (2654) & Controlled Study (974) \\
\hline Female (4139) & Procedures (2503) & Environmental Protection (926) \\
\hline Fnvironmental Management (4003) & Agriculture (2465) & Adult (881) \\
\hline Agriculture (3956) & Environmental Management (2348) & Environmental Management (877) \\
\hline Energy Utilization (3567) & United States (2236) & Male (855) \\
\hline Procedures (3507) & Male (2223) & Nonhuman (853) \\
\hline Male (3479) & Controlled Study (2170) & Agriculture (847) \\
\hline Innovation (3250) & Energy Utilization (2137) & Recycling (803) \\
\hline Carbon Dioxide (3243) & Adult (2065) & Fconomic And Social Effects (793) \\
\hline
\end{tabular}

Figure 10. Evolution of the main sustainability issues in 2011-2020.

Some topics that have lost relevance over time are United States and Energy Use, which, being respectively in positions twelve and sixteen in the long-term analysis, disappear for the short-term ranking. Likewise, innovation and carbon dioxide remain significant topics in the long term but are not protagonists in the medium and short term, while Controlled Studies and Adults appear like some of the key topics in the medium term, even increasing their relevance for the short term. Finally, in the short term, the topics of Non-human, Recycling, and Economic and social effects appear among the 20 most relevant sustainability topics, creating opportunities for new lines of research in sustainability.

Analyzing most of the bibliometric studies on sustainability, it is identified that these adopt a sectoral approach. Pizzi et al. [72] conducted a bibliometric study on the SDGs in the business sector between 2012 and 2019, identifying main research topics like technological innovation, supporting companies in developing countries, non-financial reporting, and education for SDGs, and detailing the most cited documents per year and the most cited authors. Likewise, Bhatt et al. [73] proposed a bibliometric analysis of the manufacturing sector to identify trends in green manufacturing, analyzing the number of documents per year, most cited authors, most cited documents, and identification of co-citations, which allowed them to conclude that most of the literature focuses on the relationship between lean and green practices and organizational performance from an environmental point of view. Moreover, Det and Hallinger [74] performed a bibliometric study on sustainable construction in the last 25 years based on 2877 Scopus documents, from which they analyzed the publications by country, school of thought, and institution, and the co-occurrence of keywords, highlighting four dominant topics: alternative materials for sustainable construction, sustainable construction management, recycling and waste reduction, and social sustainability in sustainable construction management.

On the other hand, Hallinger et al. [75] presented a bibliometric review on games for sustainability education between 1997 and 2019. They considered the growth of the literature in this period, geographical 
distribution, type of publications, topics with the most publications on the subject, co-occurrence of keywords, and types of research designs performed. The results indicate the predominance of non-experimental research based on web technologies and topics like environmental impact, natural resources, manufacturing production, social sustainability, and climate change. Unlike the approaches of the abovementioned studies addressing a sectoral approach, our study addresses a general approach by being based on a broader concept such as sustainability, involving the use of bibliometric techniques to classify information between 2011 and 2020 according to the number of documents, subject areas, most relevant journals, authors' leadership, documents by country, and the most cited documents. In addition, one of the main contributions of this study is related to the dynamics of the most relevant topics in sustainability in the long, medium, and short term, allowing to identify the positioning of relevant topics over time.

\subsection{The Relationship between Sustainability and Open Innovation}

When conducting the search equation in Scopus about sustainability and open innovation, 227 documents are obtained, which does not place this topic among the key topics on sustainability. However, 216 of 227 documents $(95.2 \%)$ have been published in the last 10 years, which indicates it is a growing topic that has been gaining attention in the literature, generating an average of 21.6 documents per year in the past decade. Likewise, it is identified that between 2016 and 2020, 153 documents on sustainability and open innovation were published, which represents $67.4 \%$ of documents published on this topic in the last 10 years, therefore indicating an average of 30.6 documents published per year, and confirming it is a topic that has been gaining importance in the medium term. In the short term, 77 documents addressing sustainability and open innovation were published, representing $35.6 \%$ of the documents published in the last 10 years, revealing an increase in the average number of publications per year, going from an average of 21.6 documents per year in the long term to 38.5 documents in the short term.

The joint study of sustainability and open innovation has not been one of the main topics on sustainability for the three scenarios analyzed, however, this topic is gaining attention in the literature. This trend is due to the fact that companies achieve their industrial objectives and sustainability goals by using open innovation for the development of sustainable goods and services, all this considering an inclusive innovation framework that brings together diverse stakeholders [21,76]. This implies the achievement of sustainability has become a purpose for distinct sectors, like e-commerce [67], the sharing economy [66], and those belonging to the fourth industrial revolution [23], and for diverse types of companies, like SMEs, start-ups, and large companies [65]. Likewise, the achievement of sustainable economic development rely on choices and improvements from different stakeholders like consumers, providers, and other supply chain partners [68].

Specifically, topics like open innovation dynamics, micro and macro open innovation dynamics, and open innovation engineering have focused attention on the discussions around the relationship between sustainability and open Innovation. Regarding open innovation dynamics, recent studies indicate that open innovation strategies determine the dynamic and creative change of business models, revenue business model, and responsibility business models, and the dynamics of business models will depend to a great extent the degree of open innovation of companies and interactions with official entities [66]. Similarly, it is identified that an appropriate balance between the market open innovation, closed open innovation, and social open innovation systems, which involve start-ups, SMEs, large companies, and society, will generate significant economic growth, especially when one of the systems are not completely dominant over others [65]. This implies the integration of the macro-dynamics of open innovation represented by the systems of open innovation, closed open innovation, and social innovation, and of the micro-dynamics of open innovation that can be brought together in a quadruple-helix model involving industries, universities, governments, and society [23].

Likewise, open innovation allows the generation of creative business models in a short time, for which it is critical to guarantee an open innovation-friendly culture to control and overcome the 
complexity and transaction costs that open innovation implies [67]. Even the scope of open innovation toward sustainable development can be triggered by engineering by allowing the creation of new business models that connect flows between technological innovation, business model development, market performance, and investment for continuous improvement. This relies on both the awareness of consumers' choices from the demand side and the practical improvements of production from the supply side and can be supported by big data to introduce new information about markets and society [68].

On the other hand, the bibliometric analysis focused on open innovation with sustainability identifies that the most recurrent study areas on this topic are business, management and accounting, and social sciences, where the leading issues are related to competition, smart cities, living labs (Public-Private-People partnerships where users and producers can co-create innovations), business development, co-creation, knowledge management, mitigation of climate change, and ecosystems, which in turn represent promising topics for future research on sustainability with open innovation, supporting the achievement of industry objectives and sustainability goals. Because of the interest that this topic arouses and the growth of publications in the literature, future literature reviews could apply the three scenarios proposed in this work to describe the behavior of sustainability with open innovation.

\section{Conclusions}

Sustainability represents a transdisciplinary and interdisciplinary field of research encompassing environmental, economic, and social dimensions to guarantee the fulfillment of the current and future needs of society, which has allowed its exponential growth in recent years, especially since 2004, with a significant increase in the last 10 years. This means that the documents with the highest impact index address issues related to the environment, agricultural and biological sciences, energy, engineering, chemistry, materials science, food, corporate social responsibility, technologies, economy, natural resources, and climate change; and that the most influential authors on sustainability work mainly on topics like Engineering, Energy, Environmental Science, and Business, Management and Accounting.

The bibliographic analysis performed in this study determined that North America, Europe, Asia, Oceania, and South America represent the principal territories in sustainability research, highlighting the leadership in publications by the United States, United Kingdom and China. On the other hand, the interdisciplinary and transdisciplinary approach of journals like Sustainability Switzerland and Journal Of Cleaner Production has conducted them to remain as the leading sustainability journals in the long, medium, and short term. These journals are recognized by the massive number of published articles in this field of research, allowing the publication of articles with alternative approaches and applications, addressing the current and future needs of any society, and by having a high turnover publishing policy.

The sustainability research trends that remain solid in the analyzed scenarios (long, medium, and short term) are related to sustainable development, humans, environmental sustainability, climate change, decision-making, environmental impact, economics, life cycle, and energy efficiency. In the short term, publications related to topics like China, women, and controlled studies have increased significantly. Therefore, these topics can be approached individually or jointly by researchers interested in the research field of sustainability.

Likewise, this study highlights the role of women in sustainability identifying leading female authors such as Azapagic, Penzenstadler, Streimikiene, and Frantzeskakide for the long, medium, and short term. However, female leadership in sustainability research is expected to increase, contributing directly to the achievement of the SDG 5 of gender equality. In addition, the results show that research on sustainability and women/female relates to issues of women's life stages, healthcare, psychology, leadership, and empowerment in organizations and businesses.

Future works should perform this bibliometric analysis again to determine if the dynamics of publications on sustainability changes in the number of publications, subject areas, countries with 
the leading scientific production, relevant authors, and most influential publications. Consequently, an extension of this study could evaluate the evolution of sustainability topics, opening new research lines. Since sustainable development is the most researched sustainability topic, it is recommended to perform a bibliometric analysis and literature review on sustainable development in the long, medium, and short term, and adding analysis of co-citations, school of thought, types of research designs as has been done in other bibliometric studies identified in the literature. In this way, future works could expose prominent topics and discussions around sustainable development, constituting a significant path to reach sustainability. Finally, as sustainability with open innovation represents a topic with increasing number of publications per year, future systematic literature reviews can be oriented toward the study of this topic in the three scenarios described in this work.

Author Contributions: Conceptualization, J.A.C. and A.L.-P.; Methodology, J.A.C. and A.L.-P.; Software, J.A.C.; Validation, A.L.-P.; Writing-Original Draft Preparation, J.A.C.; Writing-Review \& Editing, J.A.C. and A.L.-P.; Supervision, A.L.-P.; Project Administration, J.A.C. All authors have read and agreed to the published version of the manuscript.

Funding: This research received no external funding.

Conflicts of Interest: The authors declare no conflict of interest.

\section{References}

1. Novo, M. Environmental education, a genuine education for sustainable development. Rev. Educ. 2009, 1, 195-217.

2. Londoño, A. Metodología y Evaluación del Desarrollo Sostenible de las Subregiones que Integran el Departamento de Antioquia (Colombia), Bajo un Enfoque Sistémico Inter-Temático y Multicriterio; Universidad de Manizales: Manizales, Colombia, 2018.

3. Serna, C.A.; Londoño, A.A.; Vélez, O.A. Subnational Governance Model from the Integration of Online Media and Social Networks: The Case of Medellin City, Colombia. In Handbook of Research on Sub-National Governance and Development; IGI Global: Hershey, PA, USA, 2017; pp. 483-498.

4. WCED. Our Common Future; Oxford University Press: Oxford, UK, 1987.

5. Urquidi, V. Desarrollo Sustentable y Cambio Global; El Colegio de México: Tlalpan, Mexico, 2007.

6. Naredo, J.M. Sobre el origen, el uso y el contenido del término sostenible. Cuad. Investig. Urbanística 1996, 41, 7-18.

7. Bečić, E.; Mulej, E.M.; Švarc, J. Measuring Social Progress by Sustainable Development Indicators: Cases of Croatia and Slovenia. Procedia Soc. Behav. Sci. 2012, 37, 458-465. [CrossRef]

8. Londoño, A.; Cruz, J.G. Evaluation of sustainable development in the sub-regions of Antioquia (Colombia) using multi-criteria composite indices: A tool for prioritizing public investment at the subnational level. Environ. Dev. 2019, 1-22. [CrossRef]

9. Hidalgo, A. Pensamiento Económico Sobre Desarrollo; Universidad de Huelva: Huelva, Spain, 1998.

10. O'Riordan, T. The Politics of Sustainability. In Sustainable Environmental Management: Principles and Practice; Turner, K., Ed.; Westview Press: London, UK, 1988; pp. 29-50.

11. Holden, E.; Linnerud, K.; Banister, D. The Imperatives of Sustainable Development. Sustain. Dev. 2017, 25, 213-226. [CrossRef]

12. Shaker, R.R. The spatial distribution of development in Europe and its underlying sustainability correlations. Appl. Geogr. 2015, 63, 304-314. [CrossRef]

13. Seuring, S.; Müller, M. From a literature review to a conceptual framework for sustainable supply chain management. J. Clean. Prod. 2008, 16, 1699-1710. [CrossRef]

14. Chisti, Y. Biodiesel from microalgae. Biotechnol. Adv. 2007, 25, 294-306. [CrossRef]

15. Tilman, D.; Cassman, K.G.; Matson, P.A.; Naylor, R.; Polasky, S. Agricultural sustainability and intensive production practices. Nature 2002, 418, 671-677. [CrossRef]

16. Ostrom, E. A general framework for analyzing sustainability of social-ecological systems. Science 2009, 325, 419-423. [CrossRef]

17. Turner, J.A. Sustainable hydrogen production. Science 2004, 305, 972-974. [CrossRef] 
18. Polanco, J.; Ramírez, F.; Orozco, M. International standards effect on corporate sustainability: A senior managers' perspective. Estud. Gerenc. 2016, 32, 181-192. [CrossRef]

19. Felin, T.; Zenger, T.R. Closed or open innovation? Problem solving and the governance choice. Res. Policy 2014, 43, 914-925. [CrossRef]

20. Spithoven, A.; Vanhaverbeke, W.; Roijakkers, N. Open innovation practices in SMEs and large enterprises. Small Bus. Econ. 2013, 41, 537-562. [CrossRef]

21. Arcese, G.; Flammini, S.; Lucchetti, M.C.; Martucci, O. Evidence and Experience of Open Sustainability Innovation Practices in the Food Sector. Sustainability 2015, 7, 8067-8090. [CrossRef]

22. Ali-toudert, F.; Ji, L. Modeling and measuring urban sustainability in multi-criteria based systems-A challenging issue. Ecol. Indic. 2017, 73, 597-611. [CrossRef]

23. Yun, J.H.J.; Liu, Z. Micro and macro-dynamics of open innovation with a Quadruple-Helix model. Sustainability 2019, 11, 3301. [CrossRef]

24. Estenssoro, F. El ecodesarrollo como concepto precursor del desarrollo sustentable y su influencia en América Latina. Universum 2015, 30, 81-99. [CrossRef]

25. Estenssoro, F.; Devés, E. Antecedentes históricos del debate ambiental global: Los primeros aportes latinoamericanos al origen del concepto de Medio Ambiente y Desarrollo (1970-1980). Estud. Ibero Am. 2013, 39, 237-261. [CrossRef]

26. Maier, D.; Maier, A.; Aşchilean, I.; Anastasiu, L.; Gavriş, O. The relationship between innovation and sustainability: A bibliometric review of the literature. Sustainability 2020, 12, 4083. [CrossRef]

27. Marvuglia, A.; Havinga, L.; Heidrich, O.; Fonseca, J.; Gaitani, N.; Reckien, D. Advances and challenges in assessing urban sustainability: An advanced bibliometric review. Renew. Sustain. Energy Rev. 2020, 124, 109788. [CrossRef]

28. Jiménez-García, M.; Ruiz-Chico, J.; Peña-Sánchez, A.R.; López-Sánchez, J.A. A bibliometric analysis of sports tourism and sustainability (2002-2019). Sustainability 2020, 12, 2840. [CrossRef]

29. Bartolacci, F.; Caputo, A.; Soverchia, M. Sustainability and financial performance of small and medium sized enterprises: A bibliometric and systematic literature review. Bus. Strateg. Environ. 2020, 29, 1297-1309. [CrossRef]

30. Kitsios, F.; Kamariotou, M.; Michael, A.T. Corporate sustainability strategies and decision support methods: A bibliometric analysis. Sustainability 2020, 12, 521. [CrossRef]

31. Suriyankietkaew, S.; Petison, P. A retrospective and foresight: Bibliometric review of international research on strategic management for sustainability, 1991-2019. Sustainability 2020, 12, 91. [CrossRef]

32. Punnakitikashem, P.; Hallinger, P. Bibliometric review of the knowledge base on healthcare management for sustainability, 1994-2018. Sustainability 2020, 12, 205. [CrossRef]

33. Tseng, M.L.; Chang, C.H.; Lin, C.W.R.; Wu, K.J.; Chen, Q.; Xia, L.; Xue, B. Future trends and guidance for the triple bottom line and sustainability: A data driven bibliometric analysis. Environ. Sci. Pollut. Res. 2020, 27, 33543-33567. [CrossRef]

34. Mohadab, M.E.; Bouikhalene, B.; Safi, S. Bibliometric method for mapping the state of the art of scientific production in Covid-19. Chaos Solitons Fractals 2020, 139, 110052. [CrossRef]

35. Tang, M.; Hong, J.; Guo, S.; Liu, G.; Shen, G.Q. A bibliometric review of urban energy metabolism: Evolutionary trends and the application of network analytical methods. J. Clean. Prod. 2020, 279, 123403. [CrossRef]

36. He, S.; Zhu, D.; Chen, Y.; Liu, X.; Chen, Y.; Wang, X. Application and problems of emergy evaluation: A systemic review based on bibliometric and content analysis methods. Ecol. Indic. 2020, 114, 106304. [CrossRef]

37. Foley, J.A.; Ramankutty, N.; Brauman, K.A.; Cassidy, E.S.; Gerber, J.S.; Johnston, M.; Mueller, N.D.; O'Connell, C.; Ray, D.K.; West, P.C.; et al. Solutions for a cultivated planet. Nature 2011, 478, 337-342. [CrossRef] [PubMed]

38. Elimelech, M.; Phillip, W.A. The future of seawater desalination: Energy, technology, and the environment. Science 2011, 333, 712-717. [CrossRef] [PubMed]

39. Cardinale, B.J.; Duffy, J.E.; Gonzalez, A.; Hooper, D.U.; Perrings, C.; Venail, P.; Narwani, A.; MacE, G.M.; Tilman, D.; Wardle, D.A.; et al. Biodiversity loss and its impact on humanity. Nature 2012, 486, 59-67. [CrossRef] [PubMed] 
40. Larcher, D.; Tarascon, J.-M. Towards greener and more sustainable batteries for electrical energy storage. Nat. Chem. 2015, 7, 19-29. [CrossRef]

41. Bejan, A. Advanced Engineering Thermodynamics; Wiley: New York, NY, USA, 2016; ISBN 978-1-11-924596-4.

42. Ong, W.-J.; Tan, L.-L.; Ng, Y.H.; Yong, S.-T.; Chai, S.-P. Graphitic Carbon Nitride (g-C3N4)-Based Photocatalysts for Artificial Photosynthesis and Environmental Remediation: Are we a step closer to Achieving Sustainability? Chem. Rev. 2016, 116, 7159-7329. [CrossRef]

43. Faruk, O.; Bledzki, A.K.; Fink, H.-P.; Sain, M. Biocomposites reinforced with natural fibers: $2000-2010$. Prog. Polym. Sci. 2012, 37, 1552-1596. [CrossRef]

44. Seto, K.C.; Güneralp, B.; Hutyra, L.R. Global forecasts of urban expansion to 2030 and direct impacts on biodiversity and carbon pools. Proc. Natl. Acad. Sci. USA 2012, 109, 16083-16088. [CrossRef]

45. Lambin, E.F.; Meyfroidt, P. Global land use change, economic globalization, and the looming land scarcity. Proc. Natl. Acad. Sci. USA 2011, 108, 3465-3472. [CrossRef]

46. Aguinis, H.; Glavas, A. What We Know and Don't Know About Corporate Social Responsibility: A Review and Research Agenda. J. Manag. 2012, 38, 932-968. [CrossRef]

47. Hwang, J.-Y.; Myung, S.-T.; Sun, Y.-K. Sodium-ion batteries: Present and future. Chem. Soc. Rev. 2017, 46, 3529-3614. [CrossRef]

48. Agiwal, M.; Roy, A.; Saxena, N. Next generation 5G wireless networks: A comprehensive survey. IEEE Commun. Surv. Tutor. 2016, 18, 1617-1655. [CrossRef]

49. Ghisellini, P.; Cialani, C.; Ulgiati, S. A review on circular economy: The expected transition to a balanced interplay of environmental and economic systems. J. Clean. Prod. 2016, 114, 11-32. [CrossRef]

50. Hamari, J.; Sjöklint, M.; Ukkonen, A. The sharing economy: Why people participate in collaborative consumption. J. Assoc. Inf. Sci. Technol. 2016, 67, 2047-2059. [CrossRef]

51. Yoshimura, A.; Zhdankin, V. V Advances in Synthetic Applications of Hypervalent Iodine Compounds. Chem. Rev. 2016, 116, 3328-3435. [CrossRef]

52. Mekonnen, M.M.; Hoekstra, A.Y. Sustainability: Four billion people facing severe water scarcity. Sci. Adv. 2016, 2. [CrossRef] [PubMed]

53. Zhu, J.K. Abiotic Stress Signaling and Responses in Plants. Cell 2016, 167, 313-324. [CrossRef]

54. Geissdoerfer, M.; Savaget, P.; Bocken, N.M.P.; Hultink, E.J. The Circular Economy-A new sustainability paradigm? J. Clean. Prod. 2017, 143, 757-768. [CrossRef]

55. Willett, W.; Rockström, J.; Loken, B.; Springmann, M.; Lang, T.; Vermeulen, S.; Garnett, T.; Tilman, D.; DeClerck, F.; Wood, A.; et al. Food in the Anthropocene: The EAT-Lancet Commission on healthy diets from sustainable food systems. Lancet 2019, 393, 447-492. [CrossRef]

56. Bekun, F.V.; Alola, A.A.; Sarkodie, S.A. Toward a sustainable environment: Nexus between $\mathrm{CO}_{2}$ emissions, resource rent, renewable and nonrenewable energy in 16-EU countries. Sci. Total Environ. 2019, 657, 1023-1029. [CrossRef]

57. Yaseen, Z.M.; Sulaiman, S.O.; Deo, R.C.; Chau, K.W. An enhanced extreme learning machine model for river flow forecasting: State-of-the-art, practical applications in water resource engineering area and future research direction. J. Hydrol. 2019, 569, 387-408. [CrossRef]

58. Saberi, S.; Kouhizadeh, M.; Sarkis, J.; Shen, L. Blockchain technology and its relationships to sustainable supply chain management. Int. J. Prod. Res. 2019, 57, 2117-2135. [CrossRef]

59. Bolisetty, S.; Peydayesh, M.; Mezzenga, R. Sustainable technologies for water purification from heavy metals: Review and analysis. Chem. Soc. Rev. 2019, 48, 463-487. [CrossRef] [PubMed]

60. Destek, M.A.; Sarkodie, S.A. Investigation of environmental Kuznets curve for ecological footprint: The role of energy and financial development. Sci. Total Environ. 2019, 650, 2483-2489. [CrossRef] [PubMed]

61. Kasayanond, A.; Umam, R.; Jermsittiparsert, K. Environmental sustainability and its growth in Malaysia by elaborating the green economy and environmental efficienc. Int. J. Energy Econ. Policy 2019, 9, 465-473. [CrossRef]

62. Köhler, J.; Geels, F.W.; Kern, F.; Markard, J.; Onsongo, E.; Wieczorek, A.; Alkemade, F.; Avelino, F.; Bergek, A.; Boons, F.; et al. An agenda for sustainability transitions research: State of the art and future directions. Environ. Innov. Soc. Transit. 2019, 31, 1-32. [CrossRef]

63. Savary, S.; Willocquet, L.; Pethybridge, S.J.; Esker, P.; McRoberts, N.; Nelson, A. The global burden of pathogens and pests on major food crops. Nat. Ecol. Evol. 2019, 3, 430-439. [CrossRef] 
64. Bastin, J.F.; Finegold, Y.; Garcia, C.; Mollicone, D.; Rezende, M.; Routh, D.; Zohner, C.M.; Crowther, T.W. The global tree restoration potential. Science 2019, 364, 76-79. [CrossRef]

65. Yun, J.H.J.; Won, D.K.; Park, K.B. Entrepreneurial cyclical dynamics of open innovation. J. Evol. Econ. 2018, 28, 1151-1174. [CrossRef]

66. Yun, J.H.J.; Zhao, X.; Wu, J.; Yi, J.C.; Park, K.B.; Jung, W.Y. Business model, open innovation, and sustainability in car sharing industry-Comparing three economies. Sustainability 2020, 12, 1883. [CrossRef]

67. Yun, J.H.J.; Zhao, X.; Park, K.B.; Shi, L. Sustainability condition of open innovation: Dynamic growth of alibaba from SME to large enterprise. Sustainability 2020, 12, 4379. [CrossRef]

68. Yun, J.H.J.; Kim, D.; Yan, M.R. Open innovation engineering_Preliminary study on new entrance of technology to market. Electronics 2020, 9, 791. [CrossRef]

69. Nicolae, C.D. Gender Differences in the Scientific Production of Psychology in Spain; Universitat Jaume I: Castelló, Spain, 2019.

70. García-Peñalvo, F.J. Women and STEM disciplines in Latin America: The W-STEM European Project. J. Inf. Technol. Res. 2019, 12, 5-8.

71. D'onofrio-flores, P.; Pfafflin, S.M. Scientific-Technological Change and the Role of Women in Development; Routledge: New York, NY, USA, 2019; ISBN 978-0-36-728679-8.

72. Pizzi, S.; Caputo, A.; Corvino, A.; Venturelli, A. Management research and the UN sustainable development goals (SDGs): A bibliometric investigation and systematic review. J. Clean. Prod. 2020, 276, 124033. [CrossRef]

73. Bhatt, Y.; Ghuman, K.; Dhir, A. Sustainable manufacturing. Bibliometrics and content analysis. J. Clean. Prod. 2020, 260, 120988. [CrossRef]

74. Det, A.; Hallinger, P. A bibliometric review of research on sustainable construction, 1994-2018. J. Clean. Prod. 2020, 254, 120073. [CrossRef]

75. Hallinger, P.; Wang, R.; Chatpinyakoop, C.; Nguyen, V. A bibliometric review of research on simulations and serious games used in educating for sustainability, 1997-2019. J. Clean. Prod. 2020, 256, 120358. [CrossRef]

76. Nyström, T.; Mustaquim, M. Exploring Sustainable HCI Research Dimensions Through the Inclusive Innovation Framework. In This Changes Everything_ICT and Climate Change: What Can We Do? HCC13 2018. IFIP Advances in Information and Communication Technology; Kreps, D., Ess, C., Leenen, L., Kimppa, K., Eds.; Springer: Cham, Switzerland, 2018; ISBN 978-3-31-999605-9.

Publisher's Note: MDPI stays neutral with regard to jurisdictional claims in published maps and institutional affiliations.

(C) 2020 by the authors. Licensee MDPI, Basel, Switzerland. This article is an open access article distributed under the terms and conditions of the Creative Commons Attribution (CC BY) license (http://creativecommons.org/licenses/by/4.0/). 